\title{
Impact of Zinc, Boron and Molybdenum Addition in Soil on Mungbean Productivity, Nutrient Uptake and Economics
}

\author{
Md. Abdul Quddus ${ }^{1}$, Md. Babul Anwar ${ }^{2}$, Habib Mahammad Naser ${ }^{3}$, Md. Alamgir Siddiky ${ }^{1}$, Md. Jamal Hussain ${ }^{1}$, \\ Shamima Aktar ${ }^{4}$, A. T. M. Anwarul Islam Mondol ${ }^{3}$, Md. Anarul Islam ${ }^{5} \&$ Md. Ruhul Amin ${ }^{6}$ \\ ${ }^{1}$ Soil and Water Management Section, Horticulture Research Centre, Bangladesh Agricultural Research Institute, \\ Gazipur, Bangladesh \\ ${ }^{2}$ Regional Agricultural Research Station, Bangladesh Agricultural Research Institute, Jashore, Bangladesh \\ ${ }^{3}$ Soil Science Division, Bangladesh Agricultural Research Institute, Gazipur, Bangladesh \\ ${ }^{4}$ Pulses Research Sub-Station, Bangladesh Agricultural Research Institute, Gazipur, Bangladesh \\ ${ }^{5}$ Pomology Division, Horticulture Research Centre, Bangladesh Agricultural Research Institute, Gazipur, \\ Bangladesh \\ ${ }^{6}$ Onfarm Research Division, Bangladesh Agricultural Research Institute, Gazipur, Bangladesh \\ Correspondence: Md. Abdul Quddus, Soil and Water Management Section, Horticulture Research Centre, \\ Bangladesh Agricultural Research Institute, Gazipur, Bangladesh. E-mail: quddus06@yahoo.com
}

Received: June 9, $2020 \quad$ Accepted: July 15, $2020 \quad$ Online Published: August 15, 2020

doi:10.5539/jas.v12n9p115 URL: https://doi.org/10.5539/jas.v12n9p115

\begin{abstract}
Zinc ( $\mathrm{Zn}$ ), boron (B) and molybdenum (Mo) are essential to increase the productivity of mungbean (Vigna radiata $\mathrm{L}$.) and help to maintain the soil fertility but mostly ignored. Hence, an experiment was conducted during the years of 2016 and 2017 to know the impact of Zn, B and Mo on mungbean yield, nutrient uptake, economics and soil fertility improvement. The experiments were planned in randomized complete block design including of eight treatments with three replications. The treatments were $\mathrm{T}_{1}=$ Control, $\mathrm{T}_{2}=\mathrm{Zn} 2 \mathrm{~kg} \mathrm{ha}^{-1}, \mathrm{~T}_{3}=\mathrm{B} 1.5 \mathrm{~kg} \mathrm{ha}^{-1}$, $\mathrm{T}_{4}=$ Mo $1 \mathrm{~kg} \mathrm{ha}^{-1}, \mathrm{~T}_{5}=\mathrm{Zn}_{2} \mathrm{~B}_{1.5}, \mathrm{~T}_{6}=\mathrm{Zn}_{2} \mathrm{Mo}_{1}, \mathrm{~T}_{7}=\mathrm{B}_{1.5} \mathrm{Mo}_{1}$ and $\mathrm{T}_{8}=\mathrm{Zn}_{2} \mathrm{~B}_{1.5} \mathrm{Mo}_{1}$. The other fertilizers, $\mathrm{N}, \mathrm{P}, \mathrm{K}$ and $\mathrm{S}$ at 20, 20,30 and $10 \mathrm{~kg} \mathrm{ha}^{-1}$, respectively were used in all treatments. The results indicate that the highest seed yield $\left(1522 \mathrm{~kg} \mathrm{ha}^{-1}\right)$ was obtained from $\mathrm{T}_{8}$ treatment followed by $\mathrm{T}_{7}$. The highest percent seed yield increment $(51.6 \%)$ over control was achieved in $\mathrm{T}_{8}$ treatment. Most of the growth and yield contributing characters of mungbean were recorded highest in $\mathrm{T}_{8}$ treatment. The maximum nodulation (37.6) and highest amount of protein $(24.3 \%)$ was also obtained from $\mathrm{T}_{8}$ treatment. The $\mathrm{T}_{8}$ treatment contributed positively to attain higher total uptake of $\mathrm{N}, \mathrm{P}, \mathrm{K}, \mathrm{S}, \mathrm{Zn}$ and $\mathrm{B}$ by mungbean. The combination of $\mathrm{Zn}, \mathrm{B}$ and Mo is showed more productive compare to sole or couple use of these micronutrients. The $\mathrm{T}_{8}\left(\mathrm{Zn}_{2} \mathrm{~B}_{1.5} \mathrm{Mo}_{1} \mathrm{~kg}\right.$ ha $\left.{ }^{-1}\right)$ treatment exhibited helpful effects on soil organic matter, total $\mathrm{N}$, available $\mathrm{P}, \mathrm{Zn}$ and $\mathrm{B}$. This treatment also showed economically better on the basis of net return. Results of the present study suggest that the combination of $\mathrm{Zn}, \mathrm{B}$ and Mo applied at 2, 1.5 and $1 \mathrm{~kg} \mathrm{ha}^{-1}$, respectively could be recommended for mungbean cultivation.
\end{abstract}

Keywords: zinc, boron, molybdenum, mungbean yield, quality, nutrient uptake, economics

\section{Introduction}

Current pulses demand of Bangladesh is rising quickly for rapid growing population. But the national production of the pulses is not sufficient to meet the demand. Because, the area and production of the pulses are decreasing day by day due to occupy the boro rice and maize in cropping system through creation of irrigation facilities (Rahman, 2015). Pulses production is being also hampered due to the reduced of soil fertility making by the inappropriate and non-judicious use of inorganic fertilizers (Tarafder et al., 2020). Among pulses, mungbean (Vigna radiata L.) is the third most important pulse crop in terms of area and production in Bangladesh belonging to the family Fabaceae (Salam et al., 2017). The total area of mungbean cultivation in Bangladesh is 41421 ha with the production of $34783 \mathrm{~m}$ tones per year while the average yield is $840 \mathrm{~kg} \mathrm{ha}^{-1}$ (BBS, 2018) which indicates very low compare to potential yield $\left(1500 \mathrm{~kg} \mathrm{ha}^{-1}\right)$. Farmers of Bangladesh are generally cultivated it in Kharif-I (March to June) season, but in the Southern belt of Bangladesh it has been cultivated in late Rabi (last week of January to April) season. It is an important source of protein (21 to 32.6\%) and several 
essential nutrients (Hou et al., 2019). The mungbean sprout is used as vegetable rich in different vitamins and amino acids (Ullah et al., 2014). It improves the fertility status of soil through atmospheric nitrogen fixation (Afloabi et al., 2014). There are many reasons for low yield of mungbean. Nutrients deficiency among them, especially micronutrients like $\mathrm{Zn}, \mathrm{B}$ and Mo. Soils in the Gangetic plains of Bangladesh are more or less deficient in zinc, boron and molybdenum as well as nitrogen fixing bacteria (Rhizobium sp.) which are caused poor yield of mungbean (Quddus, 2011). Micronutrient deficiency in soil is declining the crop productivity and increasing the condition of malnutrition (Ryan et al., 2013).

However, there is great opportunity for increasing the production of mungbean globally with balanced and judicious fertilization including micronutrient using high yielding variety. Micronutrient plays an important role for improving the pulses growth, development and productivity through fixing of nitrogen by symbiotic process (Monika et al., 2020). Micronutrient like Zn plays a major role in plant growth and development (A. B. Raj \& S. K. Raj, 2019). Zinc is also involved in plant metabolism and synthesis of auxins, carbohydrate, phosphate and nucleic acid (Latef et al., 2016). It influences the activities of enzymes (e.g., dehydrogenase and carbonic anhydrase, proteinases, and peptidases), and cytochrome c synthesis, stabilization of ribosomal fractions and protection of cells against oxidative stress (Malik et al., 2015). Zinc influences the capacity of water uptake in plant and transports (Disante et al., 2011) and reduces the adverse effects of short periods of heat stress (Peck \& McDonald, 2010) or of salt stress (Tavallali et al., 2010). Zinc deficiency depressed root and shoot growth and chlorophyll concentration (Malik et al., 2015). Boron is another micronutrient essential for cell division, cell wall biosynthesis, pod and seed formation (Goldberg \& Su, 2007). It is involved in the process of nodule formation (Bolanos et al., 2001). Reproductive growth, especially flowering, fruit and seed set is more sensitive to B deficiency than vegetative growth (Islam et al., 2017). Boron enhances the flower development, pollen grain formation, pollen viability, pollen tube growth and seed development in green gram (Praveena et al., 2018). The other micronutrient- Mo is an essential component of nitrogen fixing enzyme nitrogenase and nitrate reductase (FRG, 2018). The nitrate reductase is essential in the assimilation of nitrates since it catalyses the first step of the reduction of $\mathrm{NO}_{3}$ to $\mathrm{NH}_{3}$. The other major molybdo-protein of plants includes nitrogenase, which fixes atmospheric nitrogen to $\mathrm{NH}_{3}$, which is assimilated by plants (Adesoji et al., 2009). Molybdenum deficiency in soil induced nitrogen deficiency in legumes relying on $\mathrm{N}_{2}$ fixation (Weisany et al., 2013). Molybdenum application is significantly increased the canopy, nodule formation and yield of crop (Khan et al., 2019). However, the combination of $\mathrm{Zn}, \mathrm{B}$ and Mo with macronutrients can be augmented the productivity of any legume crops (Islam et al., 2018). The encouraging effects of $\mathrm{Zn}, \mathrm{B}$ and Mo on several crops like chickpea, lentil, groundnut etc. have already been visible. On the other hand, their impacts on mungbean productivity, nutrient uptake and economics have not been explored properly. The present study was, therefore, undertaken (i) to evaluate the impacts of Zn, B and Mo on mungbean productivity, nutrient uptake and economics and the nutrient status of postharvest soil and (ii) to explore the suitable combination of micronutrient.

\section{Materials and Methods}

\subsection{Brief of Site, Soil and Climate}

The field experiment was carried out at the research field of Regional Agricultural Research Station (RARS), Bangladesh Agricultural Research Institute (BARI) in Jashore during the kharif-I season of 2016 and 2017. The experimental site was geographically placed at $23^{\circ} 11^{\prime} 15^{\prime \prime} \mathrm{N}$ latitude and $89^{\circ} 11^{\prime} 06^{\prime \prime} \mathrm{E}$ longitude and raised of $6.71 \mathrm{~m}$ above the sea level. Land type of the trial was high and belongs to Gopalpur soil series under the agroecological zone (AEZ-11), High Ganges River Floodplain. The sub-order of the soil is ochrepts under the order inceptisols. The nature of the soils are calcareous and the texture of the soil was silt loam. Starting soil pH value of the experimental field was 8.2 , organic carbon was $8.55 \mathrm{~g} \mathrm{~kg}^{-1}$, total $\mathrm{N}$ was $0.77 \mathrm{~g} \mathrm{~kg}^{-1}$, and exchangeable $\mathrm{K}$ was 0.14 meq. $100 \mathrm{~g}^{-1}$, exchangeable $\mathrm{Ca}$ was 19.0 meq. $100 \mathrm{~g}^{-1}$, available $\mathrm{P}, \mathrm{S}, \mathrm{Zn}$ and B was $14.6 \mathrm{mg} \mathrm{kg}^{-1}, 15.2 \mathrm{mg} \mathrm{kg}^{-1}, 0.84 \mathrm{mg} \mathrm{kg}^{-1}$ and $0.16 \mathrm{mg} \mathrm{kg}^{-1}$, respectively (Table 6). The climate of experimental site is subtropical and the experimental period was March to June. The rainfall was acquired from $7.9 \mathrm{~mm}$ to 165 $\mathrm{mm}$ during March to June. The mean minimum and maximum air temperatures of March to June were 18.6 and $37.9{ }^{\circ} \mathrm{C}$, respectively. In the period of study, average humidity (\%) was ranged from 76.9 to 84.6 during March to June (Table 1). 
Table 1. Weather data during the experiment period

\begin{tabular}{|c|c|c|c|c|c|c|c|c|}
\hline \multirow{3}{*}{ Months } & \multicolumn{4}{|c|}{ Avg. Temperature $\left({ }^{\circ} \mathrm{C}\right)$} & \multicolumn{2}{|c|}{ Avg. Humidity (\%) } & \multicolumn{2}{|c|}{ Rainfall (mm) } \\
\hline & \multicolumn{2}{|c|}{2016} & \multicolumn{2}{|c|}{2017} & \multirow{2}{*}{2016} & \multirow{2}{*}{2017} & \multirow{2}{*}{2016} & \multirow[t]{2}{*}{2017} \\
\hline & Min. & Max. & Min. & Max. & & & & \\
\hline March & 18.6 & 30.4 & 14.7 & 32.5 & 84.4 & 76.9 & 20 & 7.9 \\
\hline April & 24.6 & 37.9 & 16.5 & 33.5 & 79.8 & 78.4 & 45 & 107 \\
\hline May & 23.5 & 36.6 & 21.4 & 36.2 & 82.2 & 81.4 & 165 & 148 \\
\hline June & 25.9 & 31.4 & 20.1 & 34.5 & 84.6 & 82.6 & 149 & 156 \\
\hline
\end{tabular}

Source: Weather Centre, BARI, Jashore.

\subsection{Execution Procedure of Experiment}

Tractor driven disc plough was used for exposing the land and then the soil of land was prepared thoroughly by plough of a power tiller followed by laddering and leveling. Weed and stubbles was cleaned from the experimental field. The field experiment was planned in randomized complete block design including of eight treatments with three replications. The treatments were viz. $\mathrm{T}_{1}=$ Control, $\mathrm{T}_{2}=\mathrm{Zn} 2 \mathrm{~kg} \mathrm{ha}^{-1}, \mathrm{~T}_{3}=\mathrm{B} 1.5 \mathrm{~kg} \mathrm{ha}^{-1}, \mathrm{~T}_{4}$ $=$ Mo $1 \mathrm{~kg} \mathrm{ha}^{-1}, \mathrm{~T}_{5}=\mathrm{Zn}_{2} \mathrm{~B}_{1.5}, \mathrm{~T}_{6}=\mathrm{Zn}_{2} \mathrm{Mo}_{1}, \mathrm{~T}_{7}=\mathrm{B}_{1.5} \mathrm{Mo}_{1}$ and $\mathrm{T}_{8}=\mathrm{Zn}_{2} \mathrm{~B}_{1.5} \mathrm{Mo}_{1}$. The other fertilizers, $\mathrm{N}, \mathrm{P}, \mathrm{K}$ and $\mathrm{S}$ at $20,20,30$ and $10 \mathrm{~kg} \mathrm{ha}^{-1}$, respectively were used in all treatments. The unit plot size of the trial was $4 \mathrm{~m} \times 3$ $\mathrm{m}$ which separated from each other by an alley of $50 \mathrm{~cm}$ width. The replicated blocks were alienated by the space of $75 \mathrm{~cm}$ width. Micronutrients ( $\mathrm{Zn}, \mathrm{B}$ and $\mathrm{Mo}$ ) were applied as basal in the above- mentioned treatment plot. The other fertilizers were also applied as basal in all the treatment plot.The sources of N, P, K, S, Zn, B and Mo were urea, triple super phosphate (TSP), muriate of potash (MoP), gypsum, zinc sulphate, boric acid and ammonium molybdate, respectively. The healthy seeds of mungbean (cv. BARI Mung-6) were sown continued in rows (10 rows in a plot) at $35 \mathrm{~kg} \mathrm{ha}^{-1}$ maintained the space between row to row of $30 \mathrm{~cm}$ on 12 March 2016 and 13 March 2017. Hands weeding as well as thining of seedlings were done at 15 days after sowing (DAS) keeping the distance of plant to plant as $10 \mathrm{~cm}$. The unit plot $\left(12 \mathrm{~m}^{2}\right)$ was having about 400 plants.

\subsection{Intercultural Operation}

Another hand weeding was done at 40 days after seed sowing of mungbean. The Bavistin 50\% WP fungicide was sprayed at $2 \mathrm{~g} \mathrm{~L}^{-1}$ in two times on $25 \mathrm{DAS}$ and $35 \mathrm{DAS}$ for controlling the leaf spot and rot diseases. The insects (pod borer and thrips) were reduced by spraying three times of insecticide Karate (Syngenta) at $2 \mathrm{ml} \mathrm{L}^{-1}$ at flowering and podding stage interval of 10 days. Irrigation was applied as and when necessary. The mature crop was harvested at two phases. First harvest was done at $2^{\text {nd }}$ week of May and another was at $1^{\text {st }}$ week of June in both the years. Treatment wise harvested pods of mungbean were sun dried in the threshing floor for separating seeds with the help of bamboo stick.

\subsection{Data Collection}

Ten plants of mungbean were randomly selected and tagged in each treatment plot at $1^{\text {st }}$ harvest for recording the data of plant height, number of branch per plant, pod length, number of pods per plant and seeds per pod. Plant height and number of branches per plant was recorded from above ground part and averaged. Mature pods were detached from every plant and count the data of number of pods per plant and averaged. Ten pods were randomly separated from amalgamated pods of ten plant of each plot and then pod length was measured and averaged. The number of seeds per pod were counted from each pod of separated ten pods and averaged. Then treatment wise seeds of 10 plants were preserved in poly bag $(15 \times 10 \mathrm{~cm})$. The number of nodules per plant was counted at flowering stage. Five plants from each plot were smoothly uprooted and carefully removed the soil from roots in the water of plastic container. Then washed the roots with fresh water, blotted with tissue paper and counted the number of nodules per plant and averaged. Active nodules were noted by selecting of inside light-pink or red colored. The seed and stover yield $\left(\mathrm{kg} \mathrm{ha}^{-1}\right)$ per plot were recorded. Plot wise total seeds (seeds of ten plant + seeds of whole plot) were cleaned and sun dried adjusted at around 10\% moisture level measured by digital seed moisture tester manual (Seedburo 1200D Digital Moisture Tester Manual, USA). Mature plants of each plot were harvested and sundried. The dried straws were weighed as $\mathrm{kg} \mathrm{ha}^{-1}$. The 100-seed weight $(\mathrm{g})$ was determined using electronic balance by the counting of 100 seeds randomly from composite seeds of each plot.

\subsection{Procedure of Soil Samples Analysis}

Starting soil samples of the experimental field were collected $(0-15 \mathrm{~cm}$ depth) from five spot using auger and amalgamated it carefully for laboratory analysis. Postharvest soil samples of the experimental plot were collected from $0-15 \mathrm{~cm}$ depth. The combined soil sample of each plot was carried to the laboratory and it was spread on a 
brown paper for air drying. The air-dried soil samples were ground and passed through a 20-mesh sieve. After sieving, the prepared soil samples were kept into plastic containers with proper label for chemical analysis. The following method was sketched such as soil $\mathrm{pH}$ was determined by glass electrode $\mathrm{pH}$ meter using a soil-water ratio was 1:2.5 (Page et al., 1982). Wet oxidation method was used for the determination of organic carbon (Page et al., 1982). Total $\mathrm{N}$ content was determined following micro Kjeldhal method (Page et al., 1982). Available $\mathrm{P}$ was measured by Olsen method (Page et al., 1982) and available $\mathrm{S}$ was determined by extracting the soil sample with $0.15 \% \mathrm{CaCl}_{2}$ solution as described by Page et al. (1982). The reading was taken using UV visible Spectrophotometer (Varian Model 50 Conc.) at $720 \mathrm{~nm}$ and $420 \mathrm{~nm}$ wavelength for $\mathrm{P}$ and $\mathrm{S}$, respectively. Exchangeable $\mathrm{K}$ and $\mathrm{Ca}$ were extracted with $1 \mathrm{M}$ NH4OAc solution $(\mathrm{pH}=7)$ (Thomas, 1982). For exchangeable $\mathrm{K}$, the reading was taken directly using AAS (Chemito AA 203) at $766.5 \mathrm{~nm}$ wavelength. For $\mathrm{Ca}, 2 \mathrm{ml}$ aliquot was diluted with $1 \mathrm{ml}$ of $\mathrm{La}_{2} \mathrm{O}_{3}$ and $7 \mathrm{ml}$ of distilled water and then reading was taken using AAS (Chemito AA 203). Available Zn was determined by DTPA method (Lindsay \& Norvell, 1978); available B by azomethine-H method (Page et al., 1982). Available Mo was not determined due to lack of facility.

\subsection{Plant Sample Analysis}

Ground straw and seed samples were digested with di-acid mixture $\left(\mathrm{HNO}_{3}-\mathrm{HClO}_{4}\right)(5: 1)$ by Piper (1964) procedure for estimation of $\mathrm{N}$ content (Micro-Kjeldahl method), $\mathrm{P}$ (spectrophotometer method), $\mathrm{K}$ (atomic absorption spectrophotometer method) and $\mathrm{S}$ (turbidity method using $\mathrm{BaCl}_{2}$ by spectrophotometer). Zinc content in the digest was directly measured by Atomic Absorption Spectrophotometer (VARIAN SpectrAA 55B, Australia). Boron content was estimated by spectrophotometer following azomethine-H method.

\subsection{Protein Content Estimation}

The protein content in seed of mungbean was calculated by using the constant food factor 6.25 that means $(\% \mathrm{~N} \times$ 6.25) (Hiller et al., 1948)

\subsection{Nutrient Uptake Determination}

Nutrient (N, P, K, S, Zn and B) uptake by mungbean was measured from the results of crop yield and nutrient content in seed and straw (FRG, 2018).

\subsection{Statistical Analysis}

Analysis of variance was arranged following RCB design. Statistical analysis was done on nutrient (N, P, K, S, $\mathrm{Zn}$ and $\mathrm{B}$ ) content, nodulation and protein content considering the average data of two years. All data including yield and yield contributing characters obtained from the present experiment were analyzed using the statistical software of Statistix-10 (Statistix-10, 1985). The means of all data were compared using the least significant difference (LSD) test in a significant level of $\mathrm{p} \leq 0.05$.

\subsection{Economic Analysis}

In the experiment, treatment wise variable cost (cultivation cost) was measured by the addition of cost acquired from labours, ploughing and inputs. The seed yield of each treatment was converted as $\mathrm{kg} \mathrm{ha}^{-1}$. This yield was used to compute the gross return. The rent of experimental land and straw cost was not counted. Gross return of each treatment was calculated by multiplying with seed yield by the current unit price of mungbean. Net return was calculated by deducting the variable cost from gross return. Benefit cost ratio (BCR) was determined (Tithi \& Barmon, 2018) by the formula:

\section{Results and Discussion}

$$
\mathrm{BCR}=\frac{\mathrm{GR}}{\mathrm{VC}}
$$

\subsection{Yields of Mungbean}

The seed yield of mungbean was affected significantly by the application of $\mathrm{Zn}, \mathrm{B}$ and Mo during the $1^{\text {st }}$ year and $2^{\text {nd }}$ year (Table 2). The highest seed yield $\left(1485 \mathrm{~kg} \mathrm{ha}^{-1}\right)$ was recorded from the treatment $\mathrm{T}_{8}$ which was significantly higher over the other treatments, but statistically at par $\mathrm{T}_{7}$ treatment in $1^{\text {st }}$ year while in $2^{\text {nd }}$ year, the seed yield was highest $\left(1558 \mathrm{~kg} \mathrm{ha}^{-1}\right)$ in the same $T_{8}$ treatment which showed statistically identical to $T_{7}, T_{6}, T_{5}$, and $T_{4}$ treatment. The lowest seed yield was in control $\left(T_{1}\right)$ treatment. The mean seed yield ranged from 1005 to $1522 \mathrm{~kg} \mathrm{ha}^{-1}$ across the treatments. In the experiment, increment of percent mean seed yield of mungbean over control was varied from 26.5 to $51.6 \%$ across the treatments, where the highest percent seed yield increment was calculated from the treatment $T_{8}$ and the lowest was from $T_{2}$ treatment. Results of the trial indicated that every micronutrient ( $\mathrm{Zn}, \mathrm{B}$ and $\mathrm{Mo}$ ) contributed individually to help yield benefit over control. Micronutrients deficient soil is leading to low crops yield (Chude et al., 2004). However, zinc application might be boosted up 
the plant growth and yield of crops. In this study, $\mathrm{Zn}$ was significantly influenced to get seed yield increment about $26.5 \%$ over control because the status of available $\mathrm{Zn}$ in soil was low. The result is in agreement with the findigs of Rahman et al. (2017) in 50\% yield benefits of maize compared to control. Zinc is the part of reversal enzymes. It may also be involved in synthesis of protein, part of tryptophan synthetase and regulating formation of tryptophan. Zinc acts in some oxidation reduction systems and its deficiency is lead to excessive oxidation of auxins and reduction of tryptophan, leading to retardation of elongation of stems (Malik et al., 2015). Essential micronutrient boron is required for plant growth and productivity. In this trial, boron contributed $29.1 \%$ yield increment of mungbean over control due to the status of available B in soil was low. However, Fageria et al. (2007) found that boron application significantly increased common bean yield. Boron might be involved in photosynthetic and metabolic activities which enhanced crop yield. Similar judgment stated by Lalit Bhott et al. (2004) and Sathya et al. (2009). Molybdenum plays a significant role for achieving higher productivity of legume compared to non-legume crops (Baily \& Laidlaw, 1999). Molybdenum is the part of enzyme nitrogenase which is essential for the conversion of atmospheric $\mathrm{N}_{2}$ to $\mathrm{NH}_{3}$. However, Rahman et al. (2008) reported that application of molybdenum which is encouraged nodule formation and $\mathrm{N}_{2}$ fixation. Molybdenum is also involved in various metabolic processes, i.e., chlorophyll synthesis and leads to yield reduction of Mo deficiency (Liu, 2001). In this experiment, Mo significantly contributed to achieve $34.6 \%$ seed yield increment of mungbean over control. Result is in agreement with findings of Khan et al. (2019) who reported that Mo application significantly influenced to get higher biological yield of mungbean over control. On the other hand, application of double and triple micronutrients was performed better over single micronutrient although the combination of triple micronutrient which was played superior activities over paired micronutrient. Present experimental result is supported to the above explaination that triple micronutrient treatment $\mathrm{T}_{8}\left(\mathrm{Zn}_{2.0} \mathrm{~B}_{1.5} \mathrm{Mo}_{1.0}\right.$ $\mathrm{kg} \mathrm{ha}^{-1}$ ) was contributed higher yield increment $10.6 \%$ over double micronutrient treatment $\mathrm{T}_{5}=\mathrm{Zn}_{2.0} \mathrm{~B}_{1.5} \mathrm{~kg} \mathrm{ha}^{-1}$, $11.1 \%$ over treatment $\mathrm{T}_{6}=\mathrm{Zn}_{2.0} \mathrm{Mo}_{1.0} \mathrm{~kg} \mathrm{ha}^{-1}$ and $6.06 \%$ over treatment $\mathrm{T}_{7}=\mathrm{B}_{1.5} \mathrm{Mo}_{1.0} \mathrm{~kg} \mathrm{ha}^{-1}$, respectively. Similar observation was made by Islam et al. (2017), and Alam and Islam (2016) who reported that combined application of $\mathrm{Zn}$ and B showed superior effect on the yield of mungbean than their single application.Yang et al. (2009) reported that the combined application of B with Mo or Zn resulted in higher seed yield than that of application of B, Mo, or $\mathrm{Zn}$ alone, while the combined application of B, Mo, and $\mathrm{Zn}$ increased the seed yield of rapeseed by $68.1 \%$ compared to control treatment.

Table 2. Effect of Zn, B and Mo on the yields of mungbean

\begin{tabular}{|c|c|c|c|c|c|c|c|c|c|}
\hline \multirow{2}{*}{ Treatment } & \multicolumn{3}{|c|}{ Seed yield $\left(\mathrm{kg} \mathrm{ha}^{-1}\right)$} & \multicolumn{3}{|c|}{ Straw yield $\left(\mathrm{kg} \mathrm{ha}^{-1}\right)$} & \multicolumn{3}{|c|}{$\%$ Seed yield increase over control } \\
\hline & $1^{\text {st }} \mathrm{Yr}$. & $2^{\text {nd }} Y r$. & Mean & $1^{\text {st }}$ Yr. & $2^{\text {nd }} Y r$ & Mean & $1^{\text {st }} \mathrm{Yr}$. & $2^{\text {nd }} Y r$. & Mean \\
\hline $\mathrm{T}_{1}=$ Control & $1031 d$ & $978 \mathrm{c}$ & 1005 & $1874 d$ & $1832 \mathrm{c}$ & 1853 & - & - & - \\
\hline $\mathrm{T}_{2}=\mathrm{Zn}_{2} \mathrm{~kg} \mathrm{ha}^{-1}$ & $1208 \mathrm{c}$ & $1327 b$ & 1268 & $2028 \mathrm{~cd}$ & $2277 \mathrm{ab}$ & 2153 & 17.2 & 35.7 & 26.5 \\
\hline $\mathrm{T}_{3}=\mathrm{B}_{1.5} \mathrm{~kg} \mathrm{ha}^{-1}$ & $1281 \mathrm{bc}$ & $1311 b$ & 1296 & $2193 b c$ & $2160 \mathrm{~b}$ & 2177 & 24.2 & 34.0 & 29.1 \\
\hline $\mathrm{T}_{4}=\mathrm{Mo}_{1} \mathrm{~kg} \mathrm{ha}^{-1}$ & $1296 \mathrm{bc}$ & $1405 \mathrm{ab}$ & 1351 & $2179 \mathrm{bc}$ & $2416 \mathrm{ab}$ & 2298 & 25.7 & 43.6 & 34.6 \\
\hline $\mathrm{T}_{5}=\mathrm{Zn}_{2} \mathrm{~B}_{1.5}$ & $1349 b$ & $1402 \mathrm{ab}$ & 1376 & $2262 b$ & $2354 \mathrm{ab}$ & 2308 & 30.8 & 43.3 & 37.1 \\
\hline $\mathrm{T}_{6}=\mathrm{Zn}_{2} \mathrm{Mo}_{1}$ & $1358 b$ & $1381 \mathrm{ab}$ & 1370 & $2326 a b$ & $2355 \mathrm{ab}$ & 2341 & 31.7 & 41.2 & 36.5 \\
\hline $\mathrm{T}_{7}=\mathrm{B}_{1.5} \mathrm{Mo}_{1}$ & $1397 \mathrm{ab}$ & $1472 \mathrm{ab}$ & 1435 & $2334 \mathrm{ab}$ & $2490 a$ & 2412 & 35.5 & 50.5 & 43.0 \\
\hline $\mathrm{T}_{8}=\mathrm{Zn}_{2} \mathrm{~B}_{1.5} \mathrm{Mo}_{1}$ & $1485 \mathrm{a}$ & $1558 \mathrm{a}$ & 1522 & $2508 \mathrm{a}$ & $2531 \mathrm{a}$ & 2520 & 44.0 & 59.3 & 51.6 \\
\hline CV $(\%)$ & 5.42 & 8.15 & - & 5.26 & 6.82 & - & - & - & - \\
\hline $\operatorname{LSD}(0.05)$ & 124 & 193 & - & 204 & 275 & - & - & - & - \\
\hline
\end{tabular}

Note. Values within a column followed by different letters are significantly different according to the LSD test at $P \leq 0.05$. Least Significant Difference (LSD) test.

The mean straw yield of mungbean (average of two years) varied from 1853 to $2520 \mathrm{~kg} \mathrm{ha}^{-1}$ across the treatments. The highest straw yield $\left(2508 \mathrm{~kg} \mathrm{ha}^{-1}\right.$ in $1^{\text {st }}$ year and $2531 \mathrm{~kg} \mathrm{ha}^{-1}$ in $2^{\text {nd }}$ year $)$ was noted in $\mathrm{T}_{8}$ treatment which was showed significantly variation with other treatments but statistically similar to $T_{7}$ and $T_{6}$ in $1^{\text {st }}$ year and $\mathrm{T}_{7}, \mathrm{~T}_{6}, \mathrm{~T}_{5}, \mathrm{~T}_{4}$, and $\mathrm{T}_{2}$ in $2^{\text {nd }}$ year. The lowest straw yield was from control $\left(\mathrm{T}_{1}\right)$ treatment. The trend of straw yield of mungbean was similar to seed yield (Table 2). However, combined application of micronutrient was resulted superior straw yield of mungbean over their single application. Similar observation was corroborated by Jamal et al. (2018); Divyashree et al. (2018). The following growth and yield contributing characters are played vital role to achieve the improved yield of mungbean. 


\subsection{Growth and Yield Attributes of Mungbean}

Zinc, B and Mo application as singly or in combinations were exhibited significant effect on the growth and yield attributes of mungbean (Tables 3 and 4). The tallest plant $\left(52.9 \mathrm{~cm}\right.$ in $1^{\text {st }}$ year and $53.2 \mathrm{~cm}$ in $2^{\text {nd }}$ year) was recorded in the treatments $T_{8}$ which was statistically identical to the treatment $T_{7}, T_{6}, T_{5}, T_{4}$ and $T_{2}$ in $1^{\text {st }}$ and $2^{\text {nd }}$ year. Malik et al. (2015) reported that $\mathrm{Zn}$ and Mo enhanced to get higher plant height of mungbean. A similar finding was documented by Mevada et al. (2006) who reported that micronutrients ( $\mathrm{Zn}, \mathrm{B}, \mathrm{Mo}$ and $\mathrm{Fe}$ ) were influenced positively on plant height of urdbean. The mean plant height was varied from 44.9 to $53.1 \mathrm{~cm}$ across the treatments (Table 3). Significantly maximum number of branches per plant $\left(2.45\right.$ in $1^{\text {st }}$ year and 2.46 in $2^{\text {nd }}$ year) was achieved in $T_{8}$ treatment. Roy (2017) reported that maximum branches per plant of mungbean were recorded by the combined application of micronutrient. The mean number of branches per plant (average of two years) was ranged from 2.13 to 2.46 among the treatments. In case of pod length, the largest pod $\left(9.29 \mathrm{~cm}\right.$ in $1^{\text {st }}$ year and $9.14 \mathrm{~cm}$ in $2^{\text {nd }}$ year) was observed in $T_{8}$ which was significantly dissimilar to other treatments, but it was statistically alike with $\mathrm{T}_{7}, \mathrm{~T}_{6}$, and $\mathrm{T}_{5}$ treatments in $1^{\text {st }}$ year. Alam and Islam (2016) reported that combined micronutrients were contributed positively to achieve long pod of mungbean. The lowest values of all characters were obtained from the treatment $\mathrm{T}_{1}$ (Table 3 ).

Table 3. Effect of Zn, B and Mo on plant height, number branches per plant and pod length of mungbean

\begin{tabular}{|c|c|c|c|c|c|c|c|c|c|}
\hline \multirow{2}{*}{ Treatment } & \multicolumn{3}{|c|}{ Plant height $(\mathrm{cm})$} & \multicolumn{3}{|c|}{ No. of branches plant ${ }^{-1}$} & \multicolumn{3}{|c|}{ Pod length $(\mathrm{cm})$} \\
\hline & $1^{\text {st }}$ Yr. & $2^{\text {nd }} Y r$. & Mean & $1^{\text {st }}$ Yr. & $2^{\text {nd }} Y r$ & Mean & $1^{\text {st }}$ Yr. & $2^{\text {nd }} Y r$. & Mean \\
\hline $\mathrm{T}_{1}=$ Control & $43.5 \mathrm{c}$ & $46.3 c$ & 44.9 & $2.06 \mathrm{c}$ & $2.20 \mathrm{~d}$ & 2.13 & $7.38 \mathrm{~d}$ & $8.07 \mathrm{~d}$ & 7.73 \\
\hline $\mathrm{T}_{2}=\mathrm{Zn}_{2} \mathrm{~kg} \mathrm{ha}^{-1}$ & $50.2 \mathrm{ab}$ & $50.6 \mathrm{ab}$ & 50.4 & $2.20 \mathrm{~b}$ & $2.34 \mathrm{bc}$ & 2.27 & $8.60 \mathrm{c}$ & $8.34 \mathrm{~cd}$ & 8.47 \\
\hline $\mathrm{T}_{3}=\mathrm{B}_{1.5} \mathrm{~kg} \mathrm{ha}^{-1}$ & $49.2 b$ & $48.6 \mathrm{bc}$ & 48.9 & $2.16 \mathrm{bc}$ & $2.38 \mathrm{abc}$ & 2.27 & $8.91 \mathrm{bc}$ & $8.42 \mathrm{c}$ & 8.67 \\
\hline $\mathrm{T}_{4}=\mathrm{Mo}_{1} \mathrm{~kg} \mathrm{ha}^{-1}$ & $51.5 \mathrm{ab}$ & $52.7 \mathrm{a}$ & 52.1 & $2.18 \mathrm{~b}$ & $2.37 \mathrm{abc}$ & 2.28 & $8.96 b$ & $8.53 b c$ & 8.75 \\
\hline $\mathrm{T}_{5}=\mathrm{Zn}_{2} \mathrm{~B}_{1.5}$ & $52.5 \mathrm{a}$ & $53.0 \mathrm{a}$ & 52.8 & $2.17 \mathrm{bc}$ & $2.35 \mathrm{abc}$ & 2.26 & $9.09 \mathrm{ab}$ & $8.46 \mathrm{bc}$ & 8.78 \\
\hline $\mathrm{T}_{6}=\mathrm{Zn}_{2} \mathrm{Mo}_{1}$ & $51.4 \mathrm{ab}$ & $52.4 \mathrm{ab}$ & 51.9 & $2.20 \mathrm{~b}$ & $2.32 \mathrm{~cd}$ & 2.26 & $9.05 \mathrm{ab}$ & $8.47 b c$ & 8.76 \\
\hline $\mathrm{T}_{7}=\mathrm{B}_{1.5} \mathrm{Mo}_{1}$ & $50.6 \mathrm{ab}$ & $51.3 \mathrm{ab}$ & 51.0 & $2.23 b$ & $2.44 \mathrm{ab}$ & 2.34 & $9.09 \mathrm{ab}$ & $8.79 b$ & 8.94 \\
\hline $\mathrm{T}_{8}=\mathrm{Zn}_{2} \mathrm{~B}_{1.5} \mathrm{Mo}_{1}$ & $52.9 \mathrm{a}$ & $53.2 \mathrm{a}$ & 53.1 & $2.45 \mathrm{a}$ & $2.46 \mathrm{a}$ & 2.46 & $9.29 \mathrm{a}$ & $9.14 \mathrm{a}$ & 9.22 \\
\hline CV $(\%)$ & 3.17 & 4.35 & - & 2.88 & 3.03 & - & 2.14 & 2.27 & - \\
\hline $\operatorname{LSD}(0.05)$ & 2.79 & 3.88 & - & 0.12 & 0.13 & - & 0.33 & 0.34 & - \\
\hline
\end{tabular}

Note. Values within a column followed by different letters are significantly different according to the LSD test at $P \leq 0.05$.

Number of pods per plant is particularly important yield contributing character which was highly reflected to obtain highest yield of mungbean. Significantly the highest number of pods per plant ( 28.7 in $1^{\text {st }}$ year and 33.0 in $2^{\text {nd }}$ year) and seeds per pod (12.1 in $1^{\text {st }}$ year and 12.0 in $2^{\text {nd }}$ year) were recorded from the treatment $T_{8}$ and the minimum of both characters were noted in $T_{1}$ treatment (Table 4). Valenciano et al. (2011) reported that combined application of $\mathrm{Zn}, \mathrm{B}$ and Mo contributed to get maximum number of pods per plant of chickpea. Every micronutrient donated to obtain higher number of pods per plant. However, Karmakar et al. (2015) noted that $\mathrm{Zn}$ significantly influenced to attain maximum pods of mungbean. Maqbool et al. (2018) reported that yield attributes of mungbean responded to B in soil application when B availability is lower. Combined micronutrients ( $\mathrm{Zn}, \mathrm{B}$ and Mo) might be assisted in better utilization of the major nutrients (NPK) which contributed to increase the pods per plant and seeds per pod and ultimately produced the higher productivity. Similar observation was noted by Divyashree et al. (2018). In the experiment, the 100 -seeds weight was significantly influenced by different treatments (Table 4). The highest 100 -seed weight $(5.01 \mathrm{~g})$ was recorded in the treatment $\mathrm{T}_{5}$ followed by $\mathrm{T}_{8}$, $\mathrm{T}_{6}, \mathrm{~T}_{4}, \mathrm{~T}_{3}$ and $\mathrm{T}_{2}$ in $1^{\text {st }}$ year and it was recorded highest $(5.03 \mathrm{~g})$ in $\mathrm{T}_{2}$ followed by $\mathrm{T}_{8}, \mathrm{~T}_{7}, \mathrm{~T}_{6}, \mathrm{~T}_{5}, \mathrm{~T}_{4}$ and $\mathrm{T}_{3}$ treatments in $2^{\text {nd }}$ year and the lowest was in control $\left(T_{1}\right)$ treatment (Table 4). Results of the test weight was noticed that micronutrient as single or in combination might be helped to obtain higher 100-seed weight over control. The result is in agreement with the findings of Divyashree et al. (2018); Malik et al. (2015). 
Table 4. Effect of Zn, B and Mo on number of pods per plant, number of seeds per pod and 100-seeds weight of mungbean

\begin{tabular}{|c|c|c|c|c|c|c|c|c|c|}
\hline \multirow{2}{*}{ Treatment } & \multicolumn{3}{|c|}{ No. of pods plant ${ }^{-1}$} & \multicolumn{3}{|c|}{ No. of seeds pod ${ }^{-1}$} & \multicolumn{3}{|c|}{100 -seeds wt (g) } \\
\hline & $1^{\text {st }}$ Yr. & $2^{\text {nd }} Y r$. & Mean & $1^{\text {st }} \mathrm{Yr}$ & $2^{\text {nd }} \mathrm{Yr}$. & Mean & $1^{\text {st }}$ Yr. & $2^{\text {nd }} Y r$. & Mean \\
\hline $\mathrm{T}_{1}=$ Control & $23.9 \mathrm{~d}$ & $26.1 \mathrm{c}$ & 25.0 & $9.30 \mathrm{~d}$ & $10.0 \mathrm{e}$ & 9.65 & $4.50 \mathrm{~b}$ & $4.35 b$ & 4.43 \\
\hline $\mathrm{T}_{2}=\mathrm{Zn}_{2} \mathrm{~kg} \mathrm{ha}^{-1}$ & $26.4 \mathrm{bc}$ & $28.5 b c$ & 27.5 & $10.9 \mathrm{c}$ & $10.4 \mathrm{cde}$ & 10.7 & $5.00 \mathrm{a}$ & $5.03 \mathrm{a}$ & 5.02 \\
\hline $\mathrm{T}_{3}=\mathrm{B}_{1.5} \mathrm{~kg} \mathrm{ha}^{-1}$ & $25.4 \mathrm{~cd}$ & $29.4 b$ & 27.4 & $11.4 \mathrm{bc}$ & $11.3 \mathrm{abc}$ & 11.4 & $4.92 \mathrm{a}$ & $4.80 \mathrm{a}$ & 4.86 \\
\hline $\mathrm{T}_{4}=\mathrm{Mo}_{1} \mathrm{~kg} \mathrm{ha}^{-1}$ & $26.6 \mathrm{bc}$ & $31.1 \mathrm{ab}$ & 28.9 & $11.6 a b c$ & $11.0 \mathrm{bcd}$ & 11.3 & $4.83 \mathrm{ab}$ & $4.86 a$ & 4.85 \\
\hline $\mathrm{T}_{5}=\mathrm{Zn}_{2} \mathrm{~B}_{1.5}$ & $27.2 \mathrm{ab}$ & $30.2 \mathrm{ab}$ & 28.7 & $11.8 \mathrm{ab}$ & $11.1 \mathrm{bcd}$ & 11.5 & $5.01 \mathrm{a}$ & $4.67 \mathrm{ab}$ & 4.84 \\
\hline $\mathrm{T}_{6}=\mathrm{Zn}_{2} \mathrm{Mo}_{1}$ & $27.7 \mathrm{ab}$ & $30.5 \mathrm{ab}$ & 29.1 & $11.7 \mathrm{ab}$ & $10.3 \mathrm{de}$ & 11.0 & $4.83 \mathrm{ab}$ & $4.70 \mathrm{ab}$ & 4.77 \\
\hline $\mathrm{T}_{7}=\mathrm{B}_{1.5} \mathrm{Mo}_{1}$ & $26.9 b c$ & $31.6 \mathrm{ab}$ & 29.3 & $11.7 \mathrm{ab}$ & $11.8 \mathrm{ab}$ & 11.8 & $4.76 \mathrm{ab}$ & $4.73 \mathrm{ab}$ & 4.75 \\
\hline $\mathrm{T}_{8}=\mathrm{Zn}_{2} \mathrm{~B}_{1.5} \mathrm{Mo}_{1}$ & $28.7 \mathrm{a}$ & $33.0 \mathrm{a}$ & 30.9 & $12.1 \mathrm{a}$ & $12.0 \mathrm{a}$ & 12.1 & $4.84 \mathrm{ab}$ & $4.87 \mathrm{a}$ & 4.86 \\
\hline CV $(\%)$ & 3.49 & 6.13 & - & 3.69 & 4.94 & - & 4.22 & 4.87 & - \\
\hline $\operatorname{LSD}(0.05)$ & 1.63 & 3.22 & - & 0.73 & 0.95 & - & 0.36 & 0.41 & - \\
\hline
\end{tabular}

Note. Values within a column followed by different letters are significantly different according to the LSD test at $P \leq 0.05$.

\subsection{Number of Nodules Plant ${ }^{-1}$ and Protein Content of Mungbean}

The number of nodules plant ${ }^{-1}$ of mungbean responded significantly by the application of $\mathrm{Zn}, \mathrm{B}$ and Mo (Figure 1). In the experiment, application of $\mathrm{Zn}, \mathrm{B}$ and Mo either single or in combination significantly gradually augmented the number of nodules plant ${ }^{-1}$ over control. The percent increment of nodules plant ${ }^{-1}$ was ranged from 17.5 to $40.3 \%$ across the treatment. The highest increment of nodulation $(40.3 \%)$ was occurred in $\mathrm{T}_{8}$ treatment. Nodulation result of the Figure 1 exhibited that the highest number of nodules plant ${ }^{-1}$ (37.6) was documented from $T_{8}$ treatment which was significantly different with the other treatments but statistically alike to $T_{7}(36.3)$, $\mathrm{T}_{6}$ (36.9), $\mathrm{T}_{5}$ (36.7) and $\mathrm{T}_{4}$ (35.4) treatment. The lowest nodulation was found in control $\left(\mathrm{T}_{1}\right)$ treatment (Figure 1). The results also indicated that every micronutrient has an important role in nodule formation and $\mathrm{N}_{2}$ fixation (O'Hara, 2001). Zinc involved in leg haemoglobin synthesis and nodulation (Das et al., 2012; Chauhan et al., 2013). Boron played a vital role for nodule formation and symbiotic $\mathrm{N}_{2}$ fixation (Bolanos et al., 2001). Molybdenum is also a key element required to the microorganisms for nitrogen fixation (Monika et al., 2020). Application of $\mathrm{Zn}, \mathrm{B}$ and Mo either alone or in combination contributed significantly to increase the protein content in seed of mungbean (Figure 1).The protein content among the treatments varied from 21.8 to $24.3 \%$.The highest amount of protein $\left(24.3 \%\right.$ ) was obtained from $\mathrm{T}_{8}$ which was significantly higher over the other treatments but statistically similar to $\mathrm{T}_{7}(23.8 \%), \mathrm{T}_{6}(23.4 \%), \mathrm{T}_{5}(23.7 \%)$ and $\mathrm{T}_{4}(22.5 \%)$ treatment. The lowest amount of protein $(21.8 \%)$ was from control $\left(\mathrm{T}_{1}\right)$ treatment. Some similar results of protein content in different crops were corroborated by the previous studies of micronutrients application (Ram \& Katiyar, 2013; Adesoji et al., 2009; Ganie et al., 2014; Afloabi et al., 2014). 

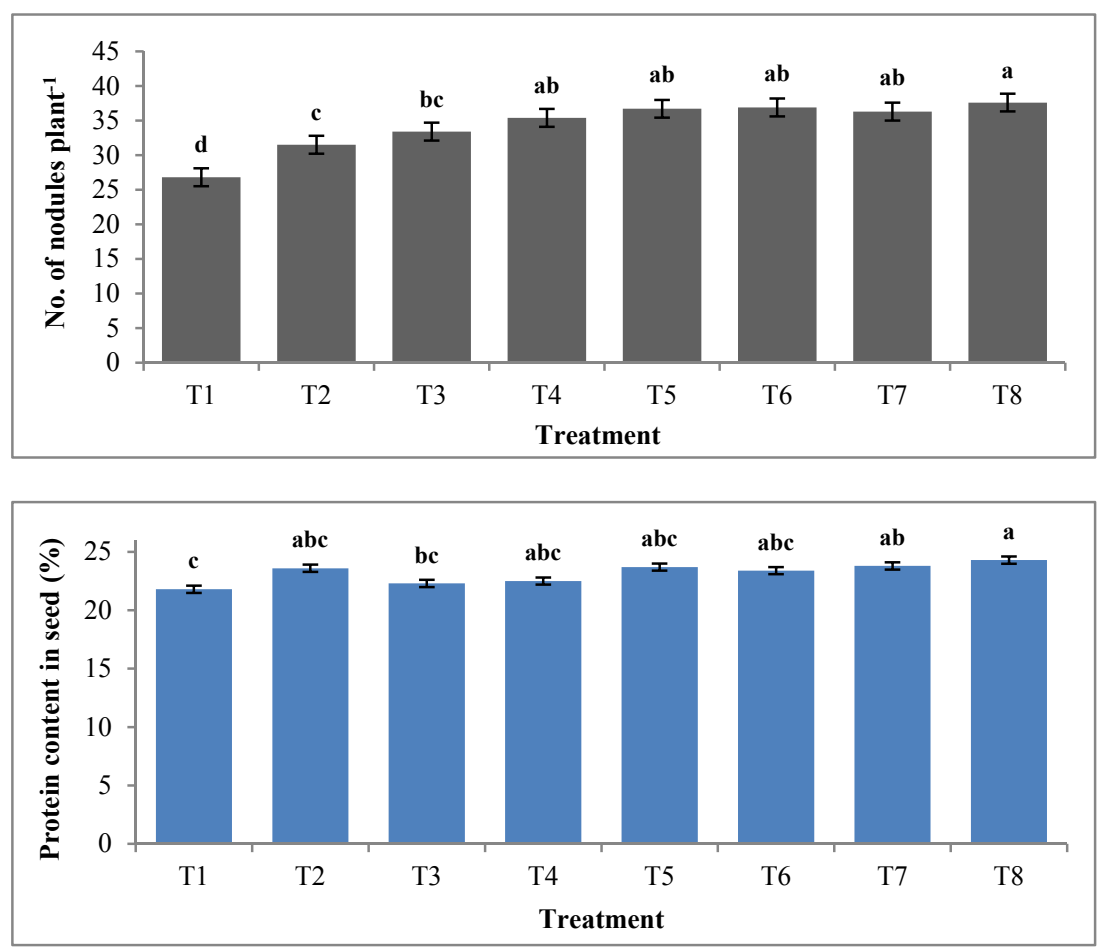

Figure 1. Effect $\mathrm{Zn}, \mathrm{B}$ and Mo on number of nodules plant ${ }^{-1}$ and protein content in seed of mungbean (mean data of two years)

Note. $\mathrm{T}_{1}=$ Control, $\mathrm{T}_{2}=\mathrm{Zn} 2 \mathrm{~kg} \mathrm{ha}^{-1}, \mathrm{~T}_{3}=\mathrm{B} 1.5 \mathrm{~kg} \mathrm{ha}^{-1}, \mathrm{~T}_{4}=$ Mo $1 \mathrm{~kg} \mathrm{ha}^{-1}, \mathrm{~T}_{5}=\mathrm{Zn}_{2} \mathrm{~B}_{1.5}, \mathrm{~T}_{6}=\mathrm{Zn}_{2} \mathrm{Mo}_{1}, \mathrm{~T}_{7}=$ $\mathrm{B}_{1.5} \mathrm{Mo}_{1}$ and $\mathrm{T}_{8}=\mathrm{Zn}_{2} \mathrm{~B}_{1.5} \mathrm{Mo}_{1}$, Error bars represent the SE (Standard Error).

Means followed by the uncommon letter (s) are significantly differ from each other according to the LSD test at $P \leq 0.05$.

\subsection{Nutrient (N, P, K, S, Zn and B) Content in Seed and Straw of Mungbean}

The content of N, P, K, S, Zn, and B in mungbean (seed and straw) was significantly influenced by the application of $\mathrm{Zn}, \mathrm{B}$ and Mo (Table 5). In the study, the highest $\mathrm{N}$ content of mungbean $\left(38.9 \mathrm{~g} \mathrm{~kg}^{-1}\right.$ in seed and $17.3 \mathrm{~g} \mathrm{~kg}^{-1}$ in straw) was recorded from $\mathrm{T}_{8}$ treatment, which was statistically equal with $\mathrm{T}_{7}, \mathrm{~T}_{6}, \mathrm{~T}_{5}, \mathrm{~T}_{4}$ and $\mathrm{T}_{2}$, although the lowest $\mathrm{N}$ content ( $34.8 \mathrm{~g} \mathrm{~kg}^{-1}$ in seed and $15.5 \mathrm{~g} \mathrm{~kg}^{-1}$ in straw) was obtained from the control $\left(\mathrm{T}_{1}\right)$ treatment. Higher $\mathrm{N}$ content in mungbean might be related with nodulation and $\mathrm{N}_{2}$ fixation. Nitrogen fixation is responded to micronutrient application. Similar judgment was made by Islam et al. (2018) in lentil. The P content of mungbean (seed and straw) influenced significantly by the application of $\mathrm{Zn}, \mathrm{B}$ and Mo as individually or in combination (Table 5). The highest amount of $\mathrm{P}\left(5.14 \mathrm{~g} \mathrm{~kg}^{-1}\right.$ in seed and $2.69 \mathrm{~g} \mathrm{~kg}^{-1}$ in straw) was found in $T_{8}$ treatment, which was statistically alike with $T_{7}, T_{6}, T_{5}, T_{4}, T_{3}$ and $T_{2}$ treatment and the lowest $P$ amount in both seed and straw of mungbean was in $\mathrm{T}_{1}$ treatment. In the experiment, micronutrient ( $\mathrm{Zn}, \mathrm{B}$, and Mo) had a significant impact on the $\mathrm{K}$ and $\mathrm{S}$ content in mungbean (seed and straw). The greatest amount of $\mathrm{K}$ ( $15.8 \mathrm{~g}$ $\mathrm{kg}^{-1}$ in seed and $21.9 \mathrm{~g} \mathrm{~kg}^{-1}$ in straw) and $\mathrm{S}\left(1.59 \mathrm{~g} \mathrm{~kg}^{-1}\right.$ in seed and $1.39 \mathrm{~g} \mathrm{~kg}^{-1}$ in straw) was obtained from $\mathrm{T}_{8}$ treatment which was non-significant to any other treatment except $\mathrm{S}$ content in straw that was showed significantly different with other treatment but statistically at par $\mathrm{T}_{7}, \mathrm{~T}_{6}$ and $\mathrm{T}_{5}$ treatment. The lowest amount of both $\mathrm{K}$ and $\mathrm{S}$ (seed and straw) was in $\mathrm{T}_{1}$ (control) treatment (Table 5). In case of $\mathrm{Zn}$ and B content, the highest $\mathrm{Zn}$ content in mungbean $\left(0.038 \mathrm{~g} \mathrm{~kg}^{-1}\right.$ in seed and $0.0376 \mathrm{~g} \mathrm{~kg}^{-1}$ in straw) was attained from the $\mathrm{T}_{8}$ treatment which was statistically comparable to $T_{6}, T_{5} \& T_{2}$ in seed and $T_{6}$ in straw. The lowest $\mathrm{Zn}$ content $\left(0.031 \mathrm{~g} \mathrm{~kg}^{-1} \mathrm{in}^{-1}\right.$ seed and $0.0339 \mathrm{~g} \mathrm{~kg}^{-1}$ in straw) was in control $\left(\mathrm{T}_{1}\right)$ treatment. The highest $\mathrm{B}$ content in mungbean $\left(0.0374 \mathrm{~g} \mathrm{~kg}^{-1}\right.$ in seed and $0.0342 \mathrm{~g} \mathrm{~kg}^{-1}$ in straw) was noted from the same $\mathrm{T}_{8}$ treatment, which was statistically identical to $\mathrm{T}_{7}$, $\mathrm{T}_{6}, \mathrm{~T}_{5} \& \mathrm{~T}_{3}$ in seed and $\mathrm{T}_{7} \& \mathrm{~T}_{5}$ in straw and the lowest $\mathrm{B}$ content (seed and straw) was from $\mathrm{T}_{1}$ treatment (Table 5). The increased $\mathrm{Zn}$ and $\mathrm{B}$ content in seed and straw was showed only in the plot receiving of $\mathrm{Zn}$ and $\mathrm{B}$ containing fertilizers. Comparable results corroborated by the some earlier studies in different crops, where 
micronutrients application were influenced on the content of P, K, S, Zn, and B (Islam et al., 2018; Divyashree et al., 2018; A. B. Raj \& S. K. Raj, 2019).

Table 5. Effect of Zn, B and Mo on nutrient content in seed and straw of mungbean (mean data of two years)

\begin{tabular}{|c|c|c|c|c|c|c|}
\hline Treatment & $\mathrm{N}$ & $\mathrm{P}$ & $\mathrm{K}$ & $\mathrm{S}$ & $\mathrm{Zn}$ & $\mathrm{B}$ \\
\hline & ---------- & -------- & - & $\mathrm{kg}^{-1}$ & -------------- & 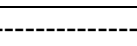 \\
\hline \multicolumn{7}{|l|}{ Seed } \\
\hline $\mathrm{T}_{1}=$ Control & $34.8 \mathrm{c}$ & $4.13 b$ & $15.1 \mathrm{a}$ & $1.42 \mathrm{a}$ & $0.031 \mathrm{c}$ & $0.0346 \mathrm{~b}$ \\
\hline $\mathrm{T}_{2}=\mathrm{Zn}_{2} \mathrm{~kg} \mathrm{ha}^{-1}$ & $37.7 \mathrm{abc}$ & $4.56 \mathrm{ab}$ & $15.5 \mathrm{a}$ & $1.51 \mathrm{a}$ & $0.035 \mathrm{abc}$ & $0.0348 b$ \\
\hline $\mathrm{T}_{3}=\mathrm{B}_{1.5} \mathrm{~kg} \mathrm{ha}^{-1}$ & $35.6 \mathrm{bc}$ & $4.61 \mathrm{ab}$ & $15.2 \mathrm{a}$ & $1.54 \mathrm{a}$ & $0.032 \mathrm{bc}$ & $0.0360 \mathrm{ab}$ \\
\hline $\mathrm{T}_{4}=\mathrm{Mo}_{1} \mathrm{~kg} \mathrm{ha}^{-1}$ & $36.5 \mathrm{abc}$ & $4.49 \mathrm{ab}$ & $15.3 \mathrm{a}$ & $1.47 \mathrm{a}$ & $0.032 b c$ & $0.0351 \mathrm{~b}$ \\
\hline $\mathrm{T}_{5}=\mathrm{Zn}_{2} \mathrm{~B}_{1.5}$ & $37.9 \mathrm{abc}$ & $4.74 \mathrm{ab}$ & $15.7 \mathrm{a}$ & $1.62 \mathrm{a}$ & $0.036 \mathrm{ab}$ & $0.0365 \mathrm{ab}$ \\
\hline $\mathrm{T}_{6}=\mathrm{Zn}_{2} \mathrm{Mo}_{1}$ & $37.4 \mathrm{abc}$ & $4.68 \mathrm{ab}$ & $15.3 \mathrm{a}$ & $1.51 \mathrm{a}$ & $0.036 \mathrm{ab}$ & $0.0353 \mathrm{ab}$ \\
\hline $\mathrm{T}_{7}=\mathrm{B}_{1.5} \mathrm{Mo}_{1}$ & $38.1 \mathrm{ab}$ & $4.59 \mathrm{ab}$ & $15.6 \mathrm{a}$ & $1.54 \mathrm{a}$ & $0.033 b c$ & $0.0368 \mathrm{ab}$ \\
\hline $\mathrm{T}_{8}=\mathrm{Zn}_{2} \mathrm{~B}_{1.5} \mathrm{Mo}_{1}$ & $38.9 \mathrm{a}$ & $5.14 \mathrm{a}$ & $15.8 \mathrm{a}$ & $1.59 \mathrm{a}$ & $0.038 \mathrm{a}$ & $0.0374 \mathrm{a}$ \\
\hline CV $(\%)$ & 4.82 & 9.39 & 4.66 & 9.83 & 7.35 & 3.53 \\
\hline $\operatorname{LSD}(0.05)$ & 3.13 & 0.76 & ns & ns & 0.004 & 0.002 \\
\hline \multicolumn{7}{|l|}{ Straw } \\
\hline $\mathrm{T}_{1}=$ Control & $15.5 b$ & $2.41 \mathrm{~b}$ & $21.1 \mathrm{a}$ & $1.10 \mathrm{c}$ & $0.0339 \mathrm{~d}$ & $0.0301 \mathrm{e}$ \\
\hline $\mathrm{T}_{2}=\mathrm{Zn}_{2} \mathrm{~kg} \mathrm{ha}^{-1}$ & $16.8 \mathrm{ab}$ & $2.49 \mathrm{ab}$ & $21.3 \mathrm{a}$ & $1.20 \mathrm{bc}$ & $0.0363 b$ & $0.0310 \mathrm{de}$ \\
\hline $\mathrm{T}_{3}=\mathrm{B}_{1.5} \mathrm{~kg} \mathrm{ha}^{-1}$ & $16.7 \mathrm{ab}$ & $2.52 \mathrm{ab}$ & $21.2 \mathrm{a}$ & $1.24 \mathrm{bc}$ & $0.0345 \mathrm{~cd}$ & $0.0330 \mathrm{~b}$ \\
\hline $\mathrm{T}_{4}=\mathrm{Mo}_{1} \mathrm{~kg} \mathrm{ha}^{-1}$ & $16.2 \mathrm{ab}$ & $2.47 \mathrm{ab}$ & $21.1 \mathrm{a}$ & $1.22 \mathrm{bc}$ & $0.0340 \mathrm{~d}$ & $0.0313 \mathrm{~cd}$ \\
\hline $\mathrm{T}_{5}=\mathrm{Zn}_{2} \mathrm{~B}_{1.5}$ & $17.1 \mathrm{ab}$ & $2.57 \mathrm{ab}$ & $21.4 \mathrm{a}$ & $1.30 \mathrm{ab}$ & $0.0368 \mathrm{~b}$ & $0.0334 \mathrm{ab}$ \\
\hline $\mathrm{T}_{6}=\mathrm{Zn}_{2} \mathrm{Mo}_{1}$ & $16.9 \mathrm{ab}$ & $2.56 \mathrm{ab}$ & $21.3 \mathrm{a}$ & $1.26 \mathrm{ab}$ & $0.0369 \mathrm{ab}$ & $0.0320 \mathrm{c}$ \\
\hline $\mathrm{T}_{7}=\mathrm{B}_{1.5} \mathrm{Mo}_{1}$ & $17.0 \mathrm{ab}$ & $2.61 \mathrm{ab}$ & $21.5 \mathrm{a}$ & $1.27 \mathrm{ab}$ & $0.0347 \mathrm{c}$ & $0.0339 \mathrm{ab}$ \\
\hline $\mathrm{T}_{8}=\mathrm{Zn}_{2} \mathrm{~B}_{1.5} \mathrm{Mo}_{1}$ & $17.3 \mathrm{a}$ & $2.69 \mathrm{a}$ & $21.9 \mathrm{a}$ & $1.39 \mathrm{a}$ & $0.0376 a$ & $0.0342 \mathrm{a}$ \\
\hline CV $(\%)$ & 5.72 & 6.26 & 3.84 & 6.45 & 1.19 & 1.68 \\
\hline $\operatorname{LSD}(0.05)$ & 1.67 & 0.28 & ns & 0.14 & 0.0074 & 0.0095 \\
\hline
\end{tabular}

Note. Values within a column followed by the same letter are not significantly different $(P \leq 0.05)$.

\subsection{Total Uptake of Nutrient (N, P, K, S, Zn and B) by Mungbean (Seed and Straw)}

Appplication of $\mathrm{Zn}, \mathrm{B}$ and Mo as single or in combination had made significant effect on total uptake of N, P, K, $\mathrm{S}, \mathrm{Zn}$ and $\mathrm{B}$ by mungbean (mean data of two years) (Figures 2 and 3). The total uptake of all nutrients by mungbean ranged across the treatment were from 63.6 to $103 \mathrm{~kg} \mathrm{~N} \mathrm{ha}^{-1}, 8.61$ to $14.6 \mathrm{~kg} \mathrm{P} \mathrm{ha}^{-1}, 54.3$ to $79.1 \mathrm{~kg} \mathrm{~K}$ $\mathrm{ha}^{-1}, 3.47$ to $5.92 \mathrm{~kg} \mathrm{~S} \mathrm{ha}^{-1}, 0.094$ to $0.153 \mathrm{~kg} \mathrm{Zn} \mathrm{ha}^{-1}$ and 0.091 to $0.143 \mathrm{~kg} \mathrm{~B} \mathrm{ha}^{-1}$. The treatment $\mathrm{T}_{8}$ (combination of $\mathrm{Zn}, \mathrm{B}$ and Mo) exhibited significantly higher uptake of total N, P, K, S, Zn and B by test crop over the other treatments. Divyashree et al. (2018) and Shashikumar et al. (2013) corroborated the similar observation in mungbean and blackgram. The lowest total uptake of all nutrients by mungbean was found in control $\left(\mathrm{T}_{1}\right)$ treatment. Results of the total uptake of all nutrients were followed the order: $\mathrm{N}>\mathrm{K}>\mathrm{P}>\mathrm{S}>\mathrm{Zn}>$ B (Figures 2 and 3). 


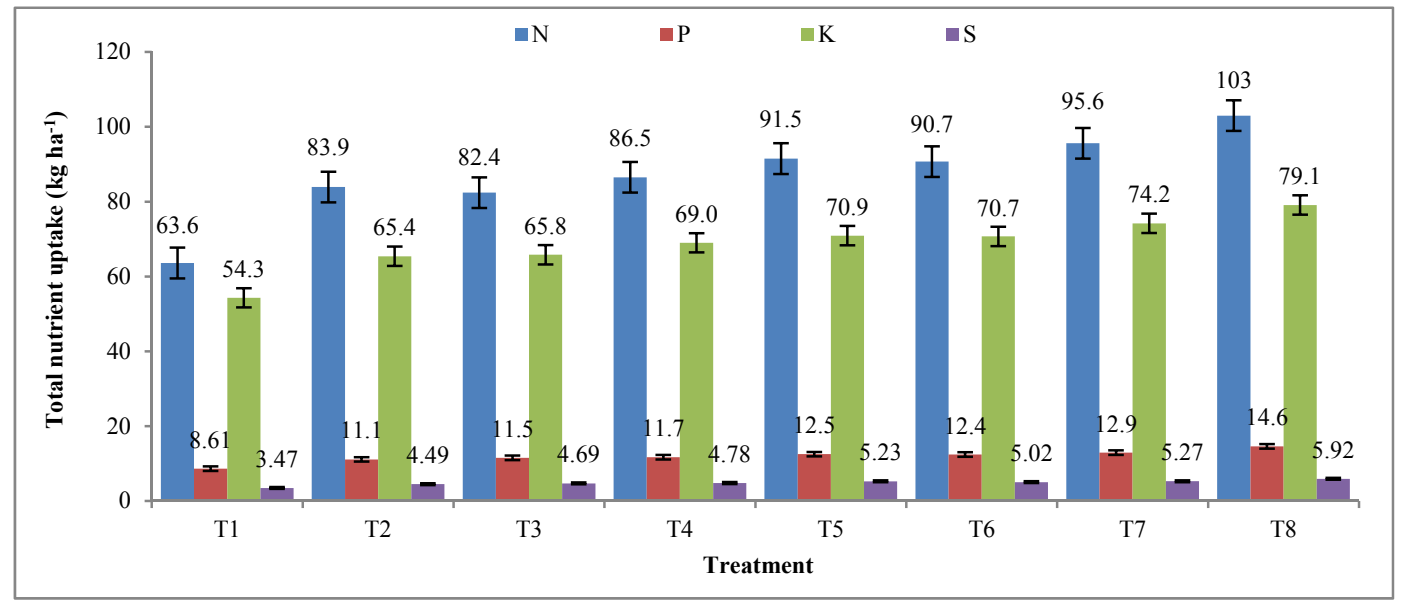

Figure 2. Effect of Zn, B and Mo on total uptake of N, P, K and S by mungbean (seed + straw)

Note. $\mathrm{T}_{1}=$ Control, $\mathrm{T}_{2}=\mathrm{Zn} 2 \mathrm{~kg} \mathrm{ha}^{-1}, \mathrm{~T}_{3}=\mathrm{B} 1.5 \mathrm{~kg} \mathrm{ha}^{-1}, \mathrm{~T}_{4}=$ Mo $1 \mathrm{~kg} \mathrm{ha}^{-1}, \mathrm{~T}_{5}=\mathrm{Zn}_{2} \mathrm{~B}_{1.5}, \mathrm{~T}_{6}=\mathrm{Zn}_{2} \mathrm{Mo}_{1}, \mathrm{~T}_{7}=$ $\mathrm{B}_{1.5} \mathrm{Mo}_{1}$ and $\mathrm{T}_{8}=\mathrm{Zn}_{2} \mathrm{~B}_{1.5} \mathrm{Mo}_{1}$, Error bars represent the SE.

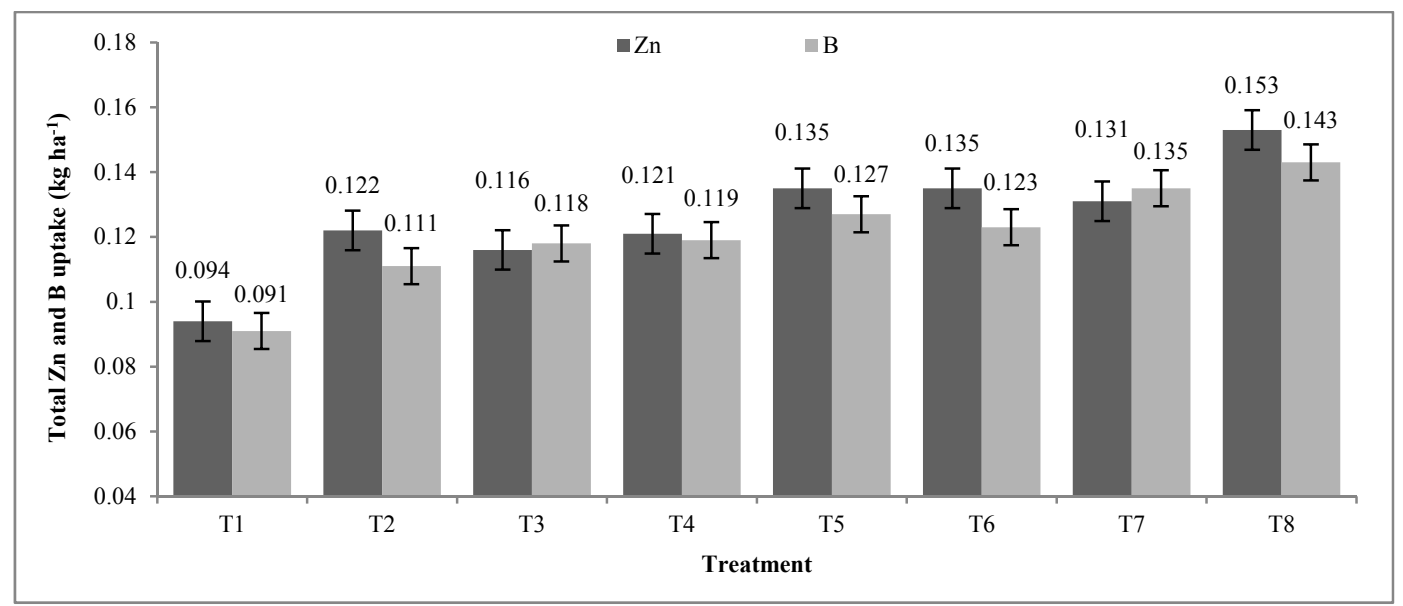

Figure 3. Effect of $Z n, B$ and Mo on total uptake of $Z n$ and $B$ by mungbean (seed + straw)

Note. $\mathrm{T}_{1}=$ Control, $\mathrm{T}_{2}=\mathrm{Zn} 2 \mathrm{~kg} \mathrm{ha}^{-1}, \mathrm{~T}_{3}=\mathrm{B} 1.5 \mathrm{~kg} \mathrm{ha}^{-1}, \mathrm{~T}_{4}=\mathrm{Mo} 1 \mathrm{~kg} \mathrm{ha}^{-1}, \mathrm{~T}_{5}=\mathrm{Zn}_{2} \mathrm{~B}_{1.5}, \mathrm{~T}_{6}=\mathrm{Zn}_{2} \mathrm{Mo}_{1}, \mathrm{~T}_{7}=$ $\mathrm{B}_{1.5} \mathrm{Mo}_{1}$ and $\mathrm{T}_{8}=\mathrm{Zn}_{2} \mathrm{~B}_{1.5} \mathrm{Mo}_{1}$, Error bars represent the SE.

\subsection{Effect of Zn, B and Mo on Postharvest Soil Properties}

Postharvest soil status of the experimental plots was influenced significantly by the application of Zn, B and Mo as single or in combination (Table 6). It has been mentioned that the available Mo was not determined. The starting soil $\mathrm{pH}$ was 8.2 , but after completion of 2 consecutive years of experiments, the soil $\mathrm{pH}$ was almost slightly decreased as compared to the starting value. This $\mathrm{pH}$ of alkaline soil might be decreased with the incorporation of stover/straw of mungbean in soil. The combined or single application of $\mathrm{Zn}, \mathrm{B}$ and Mo contributed positive increased of organic carbon (OC) in postharvest soil. The percent increment of OC ranged over starting soil was from $11.6 \%$ to $21.6 \%$ across the treatment. The highest percent increment of OC was happened in $\mathrm{T}_{8}$ treatment and lowest was in $\mathrm{T}_{1}$ treatment. Different treatments contributed to conserve the initial fertility status of soil or slightly improved of total $\mathrm{N}$ and available P. But the available $\mathrm{K}, \mathrm{S}$ and $\mathrm{Ca}$ content showed decreasing trend in all treatments with compared to the starting status. Postharvest soil status of available $\mathrm{Zn}$ and $\mathrm{B}$ content was slightly increased over starting status when the $\mathrm{Zn}$ and $\mathrm{B}$ containing fertilizers were applied, but decreased when these were not applied. In this experiment, most of the nutrient showed significantly variation among the different treatments (Table 6). The highest OC $\left(10.4 \mathrm{~g} \mathrm{~kg}^{-1}\right)$ in soil was obtained from $\mathrm{T}_{8}$ treatment which was significantly different with other treatment and the lowest $\mathrm{OC}\left(9.54 \mathrm{~g} \mathrm{~kg}^{-1}\right)$ was in control $\left(T_{1}\right)$ treatment. Significantly highest total $N\left(0.93 \mathrm{~g} \mathrm{~kg}^{-1}\right)$ was recorded from $\mathrm{T}_{8}$ treatment and lowest $\left(0.85 \mathrm{~g} \mathrm{~kg}^{-1}\right)$ was from control $\left(T_{1}\right)$ treatment. Among the treatment, the highest available nutrient of $\mathrm{P}\left(15.8 \mathrm{mg} \mathrm{kg}^{-1}\right), \mathrm{S}(15.1$ 
$\left.\mathrm{mg} \mathrm{kg}^{-1}\right), \mathrm{Zn}\left(0.93 \mathrm{mg} \mathrm{kg}^{-1}\right)$ and $\mathrm{B}\left(0.22 \mathrm{mg} \mathrm{kg}^{-1}\right)$ was significantly achieved in the same $\mathrm{T}_{8}$ treatment (Table 6). The $\mathrm{T}_{8}$ treatment contributed to produce higher amount of straw which might be more preferred to the soil microbial activities and biological properties improvement; however incorporation of straw in soil is eventually augmented the soil fertility. Kumar and Yadav (2018) corroborated the similar report.

Table 6. Effect of $\mathrm{Zn}, \mathrm{B}$ and Mo on postharvest soil $\mathrm{pH}$ and fertility status (mean data of 2 years) with reference to starting soil

\begin{tabular}{llllllllll}
\hline Treatment & $\mathrm{pH}$ & $\mathrm{OC}$ & Total N & $\mathrm{Ca}$ & $\mathrm{K}$ & $\mathrm{P}$ & $\mathrm{S}$ & $\mathrm{Zn}$ & $\mathrm{B}$ \\
\hline Starting & 8.2 & 8.55 & 0.77 & 19.0 & 0.14 & 14.6 & 15.2 & 0.84 & 0.16 \\
$\mathrm{~T}_{1}$ & $8.1 \mathrm{a}$ & $9.54 \mathrm{~d}$ & $0.85 \mathrm{f}$ & $17.5 \mathrm{a}$ & $0.13 \mathrm{a}$ & $14.1 \mathrm{~d}$ & $14.3 \mathrm{~b}$ & $0.82 \mathrm{~d}$ & $0.13 \mathrm{e}$ \\
$\mathrm{T}_{2}$ & $8.0 \mathrm{ab}$ & $10.1 \mathrm{bc}$ & $0.88 \mathrm{de}$ & $17.3 \mathrm{~b}$ & $0.13 \mathrm{a}$ & $14.0 \mathrm{~d}$ & $15.0 \mathrm{a}$ & $0.90 \mathrm{c}$ & $0.14 \mathrm{de}$ \\
$\mathrm{T}_{3}$ & $7.9 \mathrm{~b}$ & $10.0 \mathrm{c}$ & $0.87 \mathrm{e}$ & $17.4 \mathrm{ab}$ & $0.13 \mathrm{a}$ & $15.0 \mathrm{bc}$ & $15.1 \mathrm{a}$ & $0.83 \mathrm{~d}$ & $0.19 \mathrm{c}$ \\
$\mathrm{T}_{4}$ & $8.0 \mathrm{ab}$ & $10.1 \mathrm{bc}$ & $0.89 \mathrm{~cd}$ & $17.3 \mathrm{~b}$ & $0.12 \mathrm{a}$ & $15.0 \mathrm{bc}$ & $15.0 \mathrm{a}$ & $0.82 \mathrm{~d}$ & $0.15 \mathrm{~d}$ \\
$\mathrm{~T}_{5}$ & $7.9 \mathrm{~b}$ & $10.2 \mathrm{~b}$ & $0.91 \mathrm{~b}$ & $17.1 \mathrm{c}$ & $0.13 \mathrm{a}$ & $15.2 \mathrm{~b}$ & $15.0 \mathrm{a}$ & $0.91 \mathrm{bc}$ & $0.20 \mathrm{bc}$ \\
$\mathrm{T}_{6}$ & $7.9 \mathrm{~b}$ & $10.2 \mathrm{~b}$ & $0.90 \mathrm{bc}$ & $17.4 \mathrm{ab}$ & $0.13 \mathrm{a}$ & $15.0 \mathrm{bc}$ & $15.1 \mathrm{a}$ & $0.92 \mathrm{ab}$ & $0.14 \mathrm{de}$ \\
$\mathrm{T}_{7}$ & $7.9 \mathrm{~b}$ & $10.2 \mathrm{~b}$ & $0.91 \mathrm{~b}$ & $17.0 \mathrm{c}$ & $0.13 \mathrm{a}$ & $14.7 \mathrm{c}$ & $15.0 \mathrm{a}$ & $0.83 \mathrm{~d}$ & $0.21 \mathrm{ab}$ \\
$\mathrm{T}_{8}$ & $7.9 \mathrm{~b}$ & $10.4 \mathrm{a}$ & $0.93 \mathrm{a}$ & $17.1 \mathrm{c}$ & $0.12 \mathrm{a}$ & $15.8 \mathrm{a}$ & $15.1 \mathrm{a}$ & $0.93 \mathrm{a}$ & $0.22 \mathrm{a}$ \\
$\mathrm{CV}(\%)$ & 0.94 & 0.91 & 0.99 & 0.54 & 6.95 & 1.87 & 0.59 & 1.02 & 5.31 \\
\hline
\end{tabular}

Note. $\mathrm{T}_{1}=$ Control, $\mathrm{T}_{2}=\mathrm{Zn} 2 \mathrm{~kg} \mathrm{ha}^{-1}, \mathrm{~T}_{3}=\mathrm{B} 1.5 \mathrm{~kg} \mathrm{ha}^{-1}, \mathrm{~T}_{4}=$ Mo $1 \mathrm{~kg} \mathrm{ha}^{-1}, \mathrm{~T}_{5}=\mathrm{Zn}_{2} \mathrm{~B}_{1.5}, \mathrm{~T}_{6}=\mathrm{Zn}_{2} \mathrm{Mo}_{1}, \mathrm{~T}_{7}=$ $\mathrm{B}_{1.5} \mathrm{Mo}_{1}$ and $\mathrm{T}_{8}=\mathrm{Zn}_{2} \mathrm{~B}_{1.5} \mathrm{Mo}_{1}$.

Values within a column followed by the same letter are not significantly different $(P \leq 0.05)$.

\subsection{Economic Analysis}

Cost of cultivation, gross return, net return and benefit cost ratio (BCR) was influenced positively by the application of $\mathrm{Zn}, \mathrm{B}$ and Mo (Table 7). The maximum cultivation cost (BDT $38700 \mathrm{ha}^{-1} \mathrm{yr}^{-1}$ ) was spent in $\mathrm{T}_{8}$ treatment followed by $\mathrm{T}_{7}$ and $\mathrm{T}_{6}$ treatment; however the lowest (BDT $27500 \mathrm{ha}^{-1} \mathrm{yr}^{-1}$ ) cultivation cost was spent in control $\left(\mathrm{T}_{1}\right)$ treatment. In the study, the highest gross return (BDT $98930 \mathrm{ha}^{-1} \mathrm{yr}^{-1}$ ) and net return (BDT 60230 $\mathrm{ha}^{-1} \mathrm{yr}^{-1}$ ), respectively was recorded from $\mathrm{T}_{8}$ followed by $\mathrm{T}_{7}$ treatment. The lowest gross return (BDT $65325 \mathrm{ha}^{-1}$ $\mathrm{yr}^{-1}$ ) and lowest net return (BDT $37825 \mathrm{ha}^{-1} \mathrm{yr}^{-1}$ ) was found in control $\left(\mathrm{T}_{1}\right)$ treatment due to lower yield of mungbean. The benefit cost ratio (BCR) was obtained highest (2.91) from $\mathrm{T}_{5}$ treatment and lowest was in control $\left(\mathrm{T}_{1}\right)$ plot. The percent increment of benefit cost ratio across the treatment over control was varied from 0.42 to $22.3 \%$. The top increment of BCR was occurred in $\mathrm{T}_{5}$ and lowest increment was in $\mathrm{T}_{6}$ treatment (Table 7). This calculation indicated that the decreasing trend of BCR might be involved the high market price of Mo containing fertilizer. However, benefit cost ration is generated a suggestion to the Government of the People's Republic of Bangladesh for subsidizing in Mo containing fertilizer to the farmer for pulse crop production. 
Table 7. Effect of Zn, B and Mo with other inputs ${ }^{\mathrm{a}}$ on economics of mungbean production during Kharif-I season

\begin{tabular}{llllll}
\hline Treatment & $\begin{array}{l}\text { Cultivation cost } \\
\left(\mathrm{BDT}^{\mathrm{b}} \mathrm{ha}^{-1} \mathrm{yr}^{-1}\right)\end{array}$ & $\begin{array}{l}\text { Gross return } \\
\left(\mathrm{BDT} \mathrm{ha}^{-1} \mathrm{yr}^{-1}\right)\end{array}$ & $\begin{array}{l}\text { Net return } \\
\left(\mathrm{BDT} \mathrm{ha}^{-1} \mathrm{yr}^{-1}\right)\end{array}$ & $\mathrm{BCR}^{\mathrm{d}}$ & $\begin{array}{l}\text { \% increment of } \\
\mathrm{BCR}^{2} \text { over control }\end{array}$ \\
\hline $\mathrm{T}_{1}=$ Control & $27500^{\mathrm{c}}$ & 65325 & 37825 & 2.38 & - \\
$\mathrm{T}_{2}=\mathrm{Zn}_{2} \mathrm{~kg} \mathrm{ha}^{-1}$ & 29200 & 82420 & 53220 & 2.82 & 18.5 \\
$\mathrm{~T}_{3}=\mathrm{B}_{1.5} \mathrm{~kg} \mathrm{ha}^{-1}$ & 29300 & 84240 & 54940 & 2.87 & 20.6 \\
$\mathrm{~T}_{4}=\mathrm{Mo}_{1} \mathrm{~kg} \mathrm{ha}^{-1}$ & 35500 & 87815 & 52315 & 2.47 & 3.78 \\
$\mathrm{~T}_{5}=\mathrm{Zn}_{2} \mathrm{~B}_{1.5}$ & 30700 & 89440 & 58740 & 2.91 & 22.3 \\
$\mathrm{~T}_{6}=\mathrm{Zn}_{2} \mathrm{Mo}_{1}$ & 37200 & 89050 & 51850 & 2.39 & 0.42 \\
$\mathrm{~T}_{7}=\mathrm{B}_{1.5} \mathrm{Mo}_{1}$ & 37300 & 93275 & 55975 & 2.50 & 5.04 \\
$\mathrm{~T}_{8}=\mathrm{Zn}_{2} \mathrm{~B}_{1.5} \mathrm{Mo}_{1}$ & 38700 & 98930 & 60230 & 2.56 & 7.56 \\
\hline
\end{tabular}

Note. Output price: Mungbean seed at BDT $65 \mathrm{~kg}^{-1}$.

${ }^{\mathrm{a}}$ Input prices: Urea $=$ BDT $20 \mathrm{~kg}^{-1}$, T.S.P. $=$ BDT $22 \mathrm{~kg}^{-1}, \mathrm{MoP}=$ BDT $14 \mathrm{~kg}^{-1}$, Gypsum = BDT $5 \mathrm{~kg}^{-1}$, Zinc sulphate $=$ BDT $140 \mathrm{~kg}^{-1}$, Boric acid $=$ BDT $145 \mathrm{~kg}^{-1}$, Amonium molybdate $=$ BDT $14000 \mathrm{~kg}^{-1}$, Bavistin $=$ BDT 200/100 g, Karate $=$ BDT 450/500 ml, Plowing $=$ BDT 1200 ha $^{-1}$ (one pass), Wage rate $=$ BDT 300 day $^{-1}$, Mungbean seed $=$ BDT $80 \mathrm{~kg}^{-1}$.

${ }^{\mathrm{b}}$ BDT is Bangladeshi Taka (Currency); 1 USD $=82$ BDT.

${ }^{\mathrm{c}}$ Values are average of years.

${ }^{\mathrm{d}}$ Benefit Cost Ratio.

The above results and discussions are clearly indicated that micronutrient ( $\mathrm{Zn}, \mathrm{B}$ and $\mathrm{Mo})$ has significant contribution to increase the yield and quality of mungbean as well as help to sustain soil fertility.

\section{Conclusion}

Two years studied clarify that combined application of $2 \mathrm{~kg} \mathrm{Zn} \mathrm{ha}^{-1}, 1.5 \mathrm{~kg} \mathrm{~B} \mathrm{ha}^{-1}$ and $1 \mathrm{~kg} \mathrm{Mo} \mathrm{ha}^{-1}$ in soil was significantly improved the productivity and quality of mungbean.The joint micronutrients $(\mathrm{Zn}, \mathrm{B}$ and $\mathrm{Mo})$ had donated of more pods setting; more seeds pod ${ }^{-1}$ and courageous seed, which eventually boosted the seed yield. Maximum number of nodules plant ${ }^{-1}$ and the highest protein content in seed was achieved positively by the combined application of $\mathrm{Zn}, \mathrm{B}$ and Mo. The total uptake of N, P, K, S, Zn and B was also highest in the plot receiving of $2 \mathrm{~kg} \mathrm{Zn} \mathrm{ha}^{-1}, 1.5 \mathrm{~kg} \mathrm{~B} \mathrm{ha}^{-1}$ and $1 \mathrm{~kg} \mathrm{Mo} \mathrm{ha}^{-1}$. The combination of $\mathrm{Zn}, \mathrm{B}$ and Mo is showed more productive compare to sole or couple use of these micronutrients. The $\mathrm{T}_{8}\left(\mathrm{Zn}_{2} \mathrm{~B}_{1.5} \mathrm{Mo}_{1} \mathrm{~kg} \mathrm{ha}{ }^{-1}\right)$ exhibited helpful effects on soil organic carbon, total $\mathrm{N}$, available $\mathrm{P}, \mathrm{Zn}$ and $\mathrm{B}$. This treatment also showed economically better results on the basis of net return except benefit cost ratio due to high market price of Mo containing fertilizer. Results of the present study suggest that the combination of $\mathrm{Zn}, \mathrm{B}$ and Mo at 2, 1.5 and $1 \mathrm{~kg} \mathrm{ha}^{-1}$, respectively along with $\mathrm{N}, \mathrm{P}, \mathrm{K}$ and S applied at 20,20,30 and $10 \mathrm{~kg} \mathrm{ha}^{-1}$, respectively could be recommended for mungbean cultivation.

\section{References}

Adesoji, A. G., Abubakar, I. U., \& Ishaya, D. B. (2009). Performance of soybean [Glycine max (L.) Merrill] as influenced by method and rate of molybdenum application in Samaru, northern Guinea Savanna of Nigeria. American-Eurasian Journal of Sustainable Agriculture, 3(4), 845-849.

Afolabi, S. G., Adekanmbi, A. A., Adeboye, M. K., \& Bala, A. (2014). Effect of various input combinations on the growth, nodulation and yield of inoculated soybean in Minna. Nigeria. International Journal of Agriculture and Rural Development, 17(3), 2006-2011.

Alam, M. S., \& Islam, M. F. (2016). Effect of zinc and boron on seed yield and yield contributing traits of mungbean in acidic soil. J. Biosci. Agr. Res., 11(02), 941-946. https://doi.org/10.18801/jbar.110216.115

Bailey, R., \& Laidlaw, L. R. (1999). The interactive effects of P, K, lime and molybdenum on the growth and morphology of white clover (Trifolium repens L.) at establishment. Grass and Forage Sci., 16, 69-76. https://doi.org/10.1046/j.1365-2494.1999.00159.x

BBS (Bangladesh Bureau of statistics). (2018). Yearbook of Agricultural Statistics of Bangladesh-2017 (pp. 110-111). Bangladesh Bureau of Statistics, Statistics and informatics Division, Ministry of planning. Government of the People's Republic of Bangladesh, Dhaka. 
Bolanos, L., Cebrian, A., Redonto-Nieto, N., Rivilla, R., \& Bonilla, I. (2001). Lectin like glycoprotein PsNLEC-1 is not correctly glycosylated and targeted in boron deficient pea nodules. Mol. Plant Microbe Interaction, 14, 663-670. https://doi.org/10.1094/MPMI.2001.14.5.663

Chauhan, S., Titov, A., \& Tomar, D. S. (2013). Effect of potassium sulphate and zinc on growth, yield and oil content in soybean (Glycine max L.) in Vertisols of central India. Indian Journal of Applied Research, 3(6), 489-491. https://doi.org/10.15373/2249555X/JUNE2013/162

Chude V. O., Malgwi, W. B., Amapu, I. Y., \& Ano, A. O. (2004). Manual on Soil Fertility Assessment (p. 89). Federal Fertilizer Department/National Special Food Programme for Security, Abuja.

Das, S., Pareek, N., Raverkar, K. P., Chandra, R., \& Kaustav, A. (2012). Effectiveness of micronutri-ent application and Rhizobium inoculation on growth and yield of chickpea. International Journal of Agriculture Environment and Biotechnology, 5(4), 445-452.

Disante, K. B., Fuentes, D., \& Cortina, J. (2011). Response to drought of Zn stressed Quercussuber L. Seedlings. Environmental and Experimental Botany, 70, 96-103. https://doi.org/10.1016/j.envexpbot.2010.08.008

Divyashree, K. S., Prakash, S. S., Yogananda, S. B., \& Chandrappa. (2018). Seed Yield and Nutrient Content of Mungbean and Soil Nutrient Status as Influenced by Application of Micronutrients Mixture in a Alfisol. Int. J. Curr. Microbiol. App. Sci, 7(9), 1706-1713. https://doi.org/10.20546/ijcmas.2018.709.206

Divyashree, K. S., Prakash, S. S., Yogananda, S. B., \& Munawery, A. (2018). Effect of Micronutrients Mixture Application on Growth, Yield and Nutrient Uptake of Mungbean in Southern Dry Zone (Zone 6) of Karnataka. Int. J. Pure App. Biosci., 6(4), 56-62. https://doi.org/10.18782/2320-7051.6524

Fageria, N. K., Baligar, V. C., \& Zobel, R. W. (2007). Yield, nutrient uptake and soil chemical properties as influenced by liming and boron application in common bean in a no-tillage system. Communications in Soil Science and Plant Analysis, 38, 1637-1653. https://doi.org/10.1080/00103620701380413

FRG (Fertilizer Recommendation Guide). (2018). Fertilizer Recommendation Guide (pp. 1-274). Bangladesh Agricultural Research Council, Dhaka, Bangladesh.

Ganie, M. A., Akhter, F., Bhat, M. A., \& Najar, G. R. (2014). Growth yield and quality of French bean (Phaseolus vulgaris L.) as influenced by sulphur and boron application on inceptisols of Kashmir. Bioscan, 9(2), 513-518.

Goldberg, S., \& Su, C. (2007). New advances in boron soil chemistry. Advances in plant and animal boron nutrition (pp. 313-330). Springer, Netherlands. https://doi.org/10.1007/978-1-4020-5382-5_31

Hiller, A., Plazin, J., \& Vanslyke, D. D. (1948). A study of conditions of Kjeldhal determination of nitrogen in proteins. J. Bio. Chem., 176(3), 1401-1420.

Hou, D., Yousaf, L., Xue, Y., Hu, J., Wu, J., Xiaosong, H., ... Qunshen, Q. (2019). Mung Bean (Vigna radiata L.): Bioactive polyphenols, polysaccharides, peptides, and health benefits. Nutrients, 11(1238), 1-28. https://doi.org/10.3390/nu11061238

Islam, M. M., Karim, M. R., Oliver, M. M. H., Urmi, T. A., Hossain, M. A., \& Haque, M. M. (2018). Impacts of trace element addition on lentil (Lens culinaris L.). Agronomy, 8(100), 1-13. https://doi.org/10.3390/ agronomy 8070100

Islam, M. S., Hasan, K., Sarkar, N. A., Sabagh, A. E., Rashwan, E., \& Barutcular, C. (2017). Yield and yield contributing characters of mungbean as influenced by zinc and boron. Agricultural Advances, 6(1), 391-397.

Jamal, A., Khan, M. I., Tariq, M., \& Fawad, M. (2018). Response of mungbean crop to different levels of applied iron and zinc. Journal of Horticulture and Plant Research, 3, 13-22. https://doi.org/10.18052/www.scipress. com/JHPR.3.13

Karmakar, P. C., Abdullah, A. H. M., Asrafuzzaman, M., Poddar, K. K., \& Sarker, S. (2015). Effects of Zinc on the Concentrations of N, P, K, S and Zn in Mungbean (Bari Mung-6) Stover and Seed. Int. J. Res. Rev., 2(6), 307-310.

Khan, Q. A., Cheema, S. A., Farooq, M., Wakeel, A., \& Haider, F. U. (2019). Monitoring the role of molybdenum and seed priming on productivity of mung bean (Vigna radiata L.). Journal of Research in Ecology, 7(1), 2417-2427. 
Kumar, N., \& Yadav, A. (2018). Role of pulses in improving soil quality and enhancing resource use efficiency. Conservation Agriculture for Advancing Food Security in Changing Climate, 2, 547-561.

Lalit, B., Srivastava, B. K., \& Singh, M. P. M. (2004). Studies on the effect of foliar application of micronutrients on growth, yield and economics of tomato (Lycopersicon esculantum Mill). Prog. Hort., 2, 331-334.

Latef, A. A. H., Abu Alhmad, M. F., \& Abdelfattah, K. E. (2016). The possible roles of priming with ZnO nano-particles in mitigation of salinity stress in Lupine (Lupinus termis) plants. Journal of Plant Growth Regulation, 36, 60-70. https://doi.org/10.1007/s00344-016-9618-X

Lindsay, W. L., \& Norvell, W. A. (1978). Development of DTPA soil test for zinc, iron, manganese and copper. Soil Science Society of American Journal, 42(92), 421-428. https://doi.org/10.2136/sssaj1978.0361599 5004200030009x

Liu, P. (2001). The research development of molybdenum and boron nutrition in soybean. China Agricultural Science Bulletin, 17, 41-44.

Malik, K., Kumar, S., \& Arya, K. P. S. (2015). Effect of zinc, molybdenum and urea on growth and yield of mungbean (Vigna radiata L. Wilczek). Advance Research Journal of Crop Improvement, 6(1), 59-65. https://doi.org/10.15740/HAS/ARJCI/6.1/59-65

Maqbool, R., Ali, W., Nadeem, M. A., \& Abbas, T. (2018). Boron Application in Clay-Loam Soil for Improved Growth, Yield and Protein Contents of Mungbean in Water-Stresses. Sains Malaysiana, 47(1), 51-58. https://doi.org/10.17576/jsm-2018-4701-06

Mevada, K. D., Patel, J. J., \& Patel, K. P. (2006). Effect of micronutrients on yield of urdbean. Indian Journal of Pulse Research, 18(2), 214-216.

Monika, P., Yadav, R., \& Wati, L. (2020). Evaluation of combined effect of micronutrients and rhizobial inoculation on mungbean productivity. Legume Research, 43(2), 253-257.

O’Hara, G. W. (2001). Nutritional constraints on root nodule bacteria affecting symbiotic nitrogen fixation: A review. Australian Journal of Experimental Agriculture, 41, 417-433. https://doi.org/10.1071/EA00087

Page, A. L., Miller, R. H., \& Keeney, D. R. (1982). Agronomy Series 9 ASA, SSSA. Methods of Soil Analysis (Part 2, 2nd ed., pp. 403-427). American Society of Agronomy, Madison, USA.

Peck, A. W., \& McDonald, G. K. (2010). Adequate zinc nutrition alleviates the adverse effects of heat stress in bread wheat. Plant and Soil, 337, 355-374. https://doi.org/10.1007/s11104-010-0532-x

Piper, C. S. (1964). Soil and Plant Analysis. Adelaide University Press, Australia.

Praveena, R., Ghosh, G., \& Singh, V. (2018). Effect of foliar spray of boron and different zinc levels on the growth and yield of Kharif green gram (Vigna radiata). International Journal of Current Microbiology and Applied Sciences, 7(8), 1422-1428. https://doi.org/10.20546/ijcmas.2018.708.163

Quddus, M. A., Rashid, M. H., Hossain, M. A., \& Naser, H. M. (2011). Effect of zinc and boron on yield and yield contributing characters of mungbean in low Ganges river floodplain soil at Madaripur, Bangladesh. Bangladesh Journal of Agricultural Research, 36(1), 75-85. https://doi.org/10.3329/bjar.v36i1.9231

Rahman, M. A. (2015). Effect of zinc and boron on the growth and yield of mungbean (MS Thesis, Department of Soil Science, Sher-e-Bangla Agricultural University, Dhaka, Bangladesh).

Rahman, M. M. H., Sutradhar, G. C. C., Rahman, M. M., \& Paul, A. K. (2008). Effect of phosphorus, molybdenum and rhizobium inoculation on yield attributes of mungbean. International Journal of Sustainable Crop Production, 3, 26-33.

Rahman, M. T., Islam, M. R., Hasan, M. M., Ikbal, M. F., Haque, A. N. A., Shamsuzzaman, S. M., \& Rafii, M. Y. (2017). Effects of micronutrient on growth and micronutrient content of hybrid maize (Zea mays L.). Bangladesh Journal of Botany, 46(1), 527-532.

Raj, A. B., \& Raj, S. K. (2019). Zinc and boron nutrition in pulses: A review. Journal of Applied and Natural Science, 11(3), 673-679. https://doi.org/10.31018/jans.v11i3.2157

Ram, S., \& Katiyar, T. P. S. (2013). Effect of sulphur and zinc on the seed yield and protein content of summer mungbean under arid climate. International Journal of Science and Nature, 4(3), 563-566. https://doi.org/ $10.1038 /$ nclimate 1827 
Roy, M. K. (2017). Effect of boron and zinc on the growth and yield response of mungbean (MS Thesis, Department of Agronomy, Sher-E-Bangla Agricultural University, Dhaka, Bangladesh).

Ryan, J., Rashid, A., Torrent, J., Kwong, Y. S., Ibrikci, H., Sommer, R., \& Bulent, E. E. (2013). Micronutrient constraints to crop production in the Middle East-West Asia region: significance, research and management. Advances in Agronomy, 122, 1-84. https://doi.org/10.1016/B978-0-12-417187-9.00001-2

Salam, M. U., Mahalder, B. K., Sharmin, T., Sarker, P. C., Sayeed, M. A., Alam, K. M. A., ... Mahmud, A. A. (2017). Performance of mungbean in the South-Central region of Bangladesh. USAID Agricultural Extension Support Activity (AESA) Project, Banani, Dhaka, Bangladesh.

Sathya, S., Pitchai, G. J., \& Indirani, R. (2009). Boron nutrition of crops in relation to yield and quality review. Agricultural Reviews, 2, 139-144.

Shashikumar, R., Basavarajappa, S. R., Salakinkop, M. H., Basavarajappa, M. P., \& Patil, H. Y. (2013). Influence of foliar nutrition on performance of blackgram (Vigna mungo L.), nutrient uptake and economics under dry land ecosystems. Legume Research, 36(5), 422-428.

Statistix 10. (1985). An Analytical Software. Tallahassee, FL.

Tarafder, S., Rahman, M. A., Hossain, M. A., \& Chowdhury, M. A. H. (2020). Yield of Vigna radiata L. and post-harvest soil fertility in response to integrated nutrient management. Agricultural and Biological Sciences Journal, 6(1), 32-43.

Tavallali, V., Rahemi, M., Eshghi, S., Kholdebarin, B., \& Ramezanian, A. (2010). Zinc alleviates salt stress and increases antioxidant enzyme activity in the leaves of pistachio (Pistacia vera L. 'Badami') seedlings. Turkish Journal of Agriculture and Forestry, 34(4), 349-359.

Thomas, G. W. (1982). Exchangeable cations. In A. L. Page et al. (Eds.), Methods of soil analysis (Part 2). Chemical and microbiological properties (pp. 159-165). ASA Monograph (No. 9). https://doi.org/10.2134/ agronmonogr9.2.2ed.c9

Tithi, S. M., \& Barmon, B. K. (2018). Comparative advantages of lentil (Lens culinaris) and mustard (Brassica nigra L.) production and their profitability in a selected district of Bangladesh. The Agriculturists, 16(1), 21-33. https://doi.org/10.3329/agric.v16i1.37531

Ullah, R., Zain Ullah, S., Al-Deyab, S., Adnan, M., \& Tariq, A. (2014). Nutritional assessment and antioxidant activities of different varieties of Vigna radiate. The Scientific World Journal, 2014, Article ID 871753. https://doi.org/10.1155/2014/871753

Valenciano, J. B., Boto, J. A., \& Marcelo, V. (2011). Chickpea (Cicer arietinum L.) response to zinc, boron and molybdenum application under field conditions. New Zealand Journal of Crop and Horticultural Science, 39(4), 217-229. https://doi.org/10.1080/01140671.2011.577079

Weisany, W., Raei, Y., \& Allahverdipoor, K. H. (2013). Role of some of mineral nutrients in biological nitrogen fixation. Bulletin of Environment, Pharmacology and Life Sciences, 2, 77-84.

Yang, M., Shi, L., Xu, F. S., Lu, J. W., \& Wang, Y. H. (2009). Effects of B, Mo, Zn and their interactions on seed yield of rapeseed (Brassica napus L.). Pedosphere, 19, 53-59. https://doi.org/10.1016/S1002-0160 (08)60083-1

\section{Copyrights}

Copyright for this article is retained by the author(s), with first publication rights granted to the journal.

This is an open-access article distributed under the terms and conditions of the Creative Commons Attribution license (http://creativecommons.org/licenses/by/4.0/). 